\title{
Qualitative and Quantitative Analysis of 24 Components in Jinlianhua Decoction by UPLC-MS/MS
}

\author{
Mingyue Fang ${ }^{1}$. Shuangyue $\mathrm{Liu}^{1} \cdot$ Qingqing Wang ${ }^{1} \cdot$ Xuan Gu$^{1} \cdot$ Pengmin Ding $^{1} \cdot$ Weihua Wang $^{2} \cdot$ Yi Ding $^{2}$. \\ Junxiu Liu ${ }^{3} \cdot$ Rufeng Wang ${ }^{1}$
}

Received: 28 April 2019 / Revised: 6 September 2019 / Accepted: 9 September 2019 / Published online: 28 September 2019

(c) Springer-Verlag GmbH Germany, part of Springer Nature 2019

\begin{abstract}
Jinlianhua Decoction (JD), composed of Flos Trollii, Herba Taraxaci, Folium Isatidis, Radix Puerariae Lobatae, and Folium Perillae in a ratio of 6:15:10:10:6, is a prescription for Fengwen which is a group of febrile diseases due to wind in Chinese medicine. It was originally used for the prevention and treatment of severe acute respiratory syndrome (SARS), and could also be used to treat influenza due to their common pathomechanism. To elucidate the unclear pharmacodynamic basis of JD, the LC-QExactive-MS system was used to qualitatively analyze its main components in this study. As a result, 89 compounds were identified and 24 important ones were selected thereby to further perform the simultaneous quantification in 8 batches of JD samples using LC-QTrap-MS with multiple reaction monitoring (MRM). Based on the qualitative and quantitative results in combination with the bioactivities reported, 16 compounds including orientin, 2 "-O- $\beta$-L-galactopyranosylorientin, puerarin, trollisin I, rosmarinic acid, 2"-O-(2'"-methylbutanoyl) isoswertisin, daidzin, scutellarin, 3'-methoxy puerarin, vitexin, $3^{\prime}$-hydroxy puerarin, $2^{\prime \prime}-O$-(2'"-methylbutanoyl) vitexin, kaempferol, caffeic acid, 3,4-dimethoxybenzoic acid, and cynaroside were determined as the major components of JD. This study provides a useful combinational method for analyzing the major pharmacodynamic substances of JD and lays a foundation for the quality control research of the decoction.
\end{abstract}

Keywords Jinlianhua decoction · Qualitatively and quantitatively analysis · UPLC-MS/MS · Flavonoid · Phenolic acid · Alkaloid

\section{Introduction}

Jinlianhua decoction (JD) is a prescription for the prevention and treatment of severe acute respiratory syndrome (SARS) issued by State Administration of Traditional Chinese Medicine in 2003. It is an aqueous decoction made of Flos Trollii (the flowers of Trollius chinensis), Herba Taraxaci (the whole

Junxiu Liu

liujunxiusanyuan@sina.com

$\triangle$ Rufeng Wang

wangrufeng@tsinghua.org.cn

1 School of Life Sciences, Beijing University of Chinese Medicine, Yangguang South Street, Fangshan District, Beijing 102488, China

2 Drug Discovery Facility, Tsinghua University, Zhongguancun North Street, Haidian District, Beijing 100084, China

3 Department of Otorhinolaryngology, Peking University Third Hospital, No. 49, Huayuan North Road, Haidian District, Beijing 100191, China plant of Taraxacum mongolicum), Folium Isatidis (the leaves of Isatis indigotica), Radix Puerariae Lobatae (the roots of Pueraria lobata), and Folium Perillae (the leaves of Perilla frutescens) in a ratio of 6:15:10:10:6. The entire prescription has efficacies of clearing away heat and toxic material, and dispelling wind and pathogen, and thus can be used for the treatment of Fengwen disease. According to traditional Chinese medicine (TCM), Fengwen is a group of warm diseases caused by exogenous evils of wind and heat, which occurs in the warm and windy spring or in the late winter. It starts with fever, cold intolerance, headache, cough and other mild pulmonary symptoms. In addition to SARS, influenza in western medicine or so-called seasonal cold in Chinese medicine also belongs to the category of warm diseases [1]. In Chinese medicine, the treatment of warm diseases not only focuses on direct elimination of influenza virus, but also highlights the relationship among virus, organism and drug. Thus, dialectical treatment through improving the state of human body and regulating its capacity of disease resistance is preferred. Studies have shown that the abnormal increase of various inflammatory cytokines 
as the influenza virus infects the body is the basis of immune damage [2]. TCM not only directly inhibits the replication of influenza virus, but also protects the human body from the damage caused by the virus through regulating the expression of inflammatory factors and the immune network in the body [3]. It is well known that the pharmacological actions of TCM are closely related to its chemical composition. In the previous studies, we have confirmed the anti-influenza effect of JD [4], and have quantitatively analyzed a part of the components in this decoction by high-performance liquid chromatography (HPLC) [5]. However, this is not enough for elucidation of its effective substances because the efficacy of TCM is the result of synergistic effects of multiple effective components [6]. Consequently, the comprehensive study of the composition of JD is of great significance for revealing its acting mechanism.

Although there is still technical difficulty in fully understanding the composition of TCM, ultra-high-performance liquid chromatography (UHPLC) shows great advantages in the separation and analysis of complex systems such as TCM due to its ultra-high efficiency, resolution and sensitivity. UHPLC tandem quadrupole-electrostatic field orbitrap high-resolution mass spectrometry (UHPLC-QExactiveMS) system with high-throughput scanning and multiple detection capabilities can provide high-quality mass spectra and accurate molecular weight of compounds. It has been applied to multi-component microanalysis, so as to realize the separation and qualitative detection of the compounds in complex systems [7]. Another technique quadrupole-linear ion trap mass spectrometry (QTrap), which uses a multiple reaction monitoring information-dependent acquisitionenhanced product ion scanning (MRM-IDA-EPI) detection mode [8], can obtain the high-quality MS/MS spectra of parent ions in the corresponding MRM channel to double characterize the unknown compounds and improve the accuracy of the qualitative analysis. Furthermore, it also can use the high-selectivity and high-sensitivity MRM scan to obtain the peak area of the compounds for quantitative analysis. In view of this, we used LC-QExactive-MS and LC-QTrap-MS to qualitatively and quantitatively analyze the constituents of JD, respectively, to provide a basis for the determination of pharmacodynamic substance basis. In addition, we used morphological identification in combination with DNA barcoding technique [9] to identify the crude drugs used in the preparation of JD decoction.

\section{Materials and Methods}

\section{Crude Drugs}

The five crude drugs including Flos Trollii, Herba Taraxaci, Folium Isatidis, Radix Puerariae Lobatae, and Folium Perillae were purchased from materia medica markets or drugstores in various regions of China (Table 1), and the voucher specimens have been deposited at the Herbarium of School of Life Sciences, Beijing University of Chinese Medicine.

\section{Reagents and Materials}

Thermo UHPLC series quadrupole-electrostatic field orbitrap high-resolution mass (Ultimate3000 QExactive plus LC-MS) spectrometer, the data processing software Xcalibur and Compound Discoverer (CD) 2.1 were the products of Thermo Fisher Scientific (Pittsburgh, PA, USA). Acquity ultra-performance liquid chromatograph (UPLC) was from Waters Corporation (Milford, MA, USA). AB Sciex QTrap 4500 triple quadrupole mass spectrometer equipped with an electrospray ionization (ESI) source and the data processing software Analyst 1.6.1 was manufactured by AB Sciex Pte. Ltd. (Framingham, MA, USA). Sigma 1-14 desktop highspeed centrifuge was the product of Sigma-Aldrich, Inc. (St. Louis, MO, USA). Milli-Q integral water purification system was produced by Millipore Corporation (Bedford, MA, USA). METTLER TOLEDO Xp26 one-millionth electronic analytical balance was from METTLER TOLEDO (Zurich, CH). IKA VORTEX GENIUS 3 vortex mixer was made by Janke \& Kunkel KG.IKA-werk (Staufen, DE). LongGene thermal cycle analyzer was provided by Hangzhou Langji Scientific Instrument Co., Ltd. (Hangzhou, Zhejiang, China). BG-gdsAUTO510 gel imaging system was the product of Beijing Bay Gene Biotechnology Co., Ltd. (Beijing, China). DYY-6C electrophoresis apparatus was provided by Beijing Liuyi Device Factory (Beijing, China). KQ-500DE CNC ultrasonic cleaner was provided by Kunshan Ultrasonic Instrument Co. Ltd. (Kunshan, Jiangsu, China). Methanol and acetonitrile of LC-MS grade were manufactured by Fisher Scientific (Pittsburgh, PA, USA). Formic acid of chromatographic grade was the product of Tedia Company, Inc (Fairfield, Ohio, USA). DNA rapid extraction kit for broad spectrum plant genome, $2 \times$ Taq PCR Master Mix enzyme, and BM2000+DNA Marker were purchased from Beijing Bomaide Biotechnology Co., Ltd. (Beijing, China). Deionized water was purified by Milli-Q system. All other chemicals were available products of at least analytical grade.

Reference compounds including genistin, apigenin, daidzin, kaempferol, rutin, scutellarin, vitexin, ferulic acid, 3 '-hydroxy puerarin, 2 "- $O-\beta$-L-galactopyranosylorientin, indirubin and cynaroside were bought from Shanghai Yuanye Biotech Co., Ltd. (Shanghai, China). 3'-Methoxy puerarin was purchased from Chengdu Push Biotech Co., Ltd. (Chengdu, Sichuan, China). Caffeic acid was from Chengdu Pufei De Biotech Co., Ltd. (Chengdu, Sichuan, China). Orientin was from Pharmacodia (Beijing) Co., Ltd. (Beijing, China). Puerarin and rosmarinic acid were 
Table 1 Morphological and molecular identification of crude drugs

\begin{tabular}{|c|c|c|c|c|c|c|}
\hline ID & Crude drug & Sample number & Place of purchase & $\begin{array}{l}\text { Morphological } \\
\text { identification }\end{array}$ & $\begin{array}{l}\text { Genenbank } \\
\text { registration } \\
\text { number }\end{array}$ & $\begin{array}{l}\text { Molecular identifica- } \\
\text { tion }\end{array}$ \\
\hline \multirow[t]{5}{*}{ HB-2-20171123 } & Flos Trollii & HB-2-FT & $\begin{array}{l}\text { Anguo, Hebei } \\
\text { province }\end{array}$ & Trollius chinensis & KC004044.1 & Trollius chinensis \\
\hline & $\begin{array}{l}\text { Radix Puerariae } \\
\text { Lobatae }\end{array}$ & HB-2-RPL & $\begin{array}{l}\text { Anguo, Hebei } \\
\text { province }\end{array}$ & Pueraria lobata & KY860933.1 & Pueraria lobata \\
\hline & Folium Isatidis & HB-2-FI & $\begin{array}{l}\text { Anguo, Hebei } \\
\text { province }\end{array}$ & $\begin{array}{l}\text { Polygonum tincto- } \\
\text { rium }\end{array}$ & MG730606.1 & Polygonum tinctorium \\
\hline & Folium Perillae & HB-2-FP & $\begin{array}{l}\text { Anguo, Hebei } \\
\text { province }\end{array}$ & Perilla frutescens & KT220698.1 & Perilla frutescens \\
\hline & Herba Taraxaci & HB-2-HT & $\begin{array}{l}\text { Anguo, Hebei } \\
\text { province }\end{array}$ & $\begin{array}{l}\text { Taraxacum alaska- } \\
\text { num }\end{array}$ & MG219040.1 & $\begin{array}{l}\text { Taraxacum alaska- } \\
\text { num }\end{array}$ \\
\hline \multirow[t]{5}{*}{ SZ-1-20171128 } & Flos Trollii & HB-1-FT & $\begin{array}{l}\text { Anguo, Hebei } \\
\text { province }\end{array}$ & Trollius chinensis & KC004044.1 & Trollius chinensis \\
\hline & $\begin{array}{l}\text { Radix Puerariae } \\
\text { Lobatae }\end{array}$ & SZ-1-RPL & $\begin{array}{l}\text { Shenzhen, Guang- } \\
\text { dong province }\end{array}$ & Pueraria lobata & KY860933.1 & Pueraria lobata \\
\hline & Folium Isatidis & SZ-1-FI & $\begin{array}{l}\text { Shenzhen, Guang- } \\
\text { dong province }\end{array}$ & Isatis indigotica & MG730905.1 & Isatis indigotica \\
\hline & Folium Perillae & SZ-1-FP & $\begin{array}{l}\text { Shenzhen, Guang- } \\
\text { dong province }\end{array}$ & Perilla frutescens & KR082768.1 & Perilla frutescens \\
\hline & Herba Taraxaci & SZ-1-HT & $\begin{array}{l}\text { Shenzhen, Guang- } \\
\text { dong province }\end{array}$ & $\begin{array}{l}\text { Taraxacum mongoli- } \\
\text { cum }\end{array}$ & JN407433.1 & $\begin{array}{l}\text { Taraxacum mongoli- } \\
\text { cum }\end{array}$ \\
\hline \multirow[t]{5}{*}{ CD-1-20171127 } & Flos Trollii & CD-1-FT & $\begin{array}{l}\text { Chengdu, Sichuan } \\
\text { province }\end{array}$ & Trollius chinensis & КC004044.1 & Trollius chinensis \\
\hline & $\begin{array}{l}\text { Radix Puerariae } \\
\text { Lobatae }\end{array}$ & CD-1-RPL & $\begin{array}{l}\text { Chengdu, Sichuan } \\
\text { province }\end{array}$ & Pueraria thomsonii & MG236579.1 & Pueraria thomsonii \\
\hline & Folium Isatidis & CD-1-FI & $\begin{array}{l}\text { Chengdu, Sichuan } \\
\text { province }\end{array}$ & Isatis indigotica & DQ813301.1 & Isatis indigotica \\
\hline & Folium Perillae & CD-1-FP & $\begin{array}{l}\text { Chengdu, Sichuan } \\
\text { province }\end{array}$ & Perilla frutescens & MG731094.1 & Perilla frutescens \\
\hline & Herba Taraxaci & CD-1-HT & $\begin{array}{l}\text { Chengdu, Sichuan } \\
\text { province }\end{array}$ & $\begin{array}{l}\text { Taraxacum mongoli- } \\
\quad \text { cum }\end{array}$ & AY548210.1 & $\begin{array}{l}\text { Taraxacum mongoli- } \\
\text { cum }\end{array}$ \\
\hline \multirow[t]{5}{*}{ HB-1-20171123 } & Flos Trollii & HB-1-FT & $\begin{array}{l}\text { Anguo, Hebei } \\
\text { province }\end{array}$ & Trollius chinensis & KC004044.1 & Trollius chinensis \\
\hline & $\begin{array}{l}\text { Radix Puerariae } \\
\text { Lobatae }\end{array}$ & HB-1-RPL & $\begin{array}{l}\text { Anguo, Hebei } \\
\text { province }\end{array}$ & Pueraria lobata & KY860933.1 & Pueraria lobata \\
\hline & Folium Isatidis & HB-1-FI & $\begin{array}{l}\text { Anguo, Hebei } \\
\text { province }\end{array}$ & Isatis indigotica & DQ813301.1 & Isatis indigotica \\
\hline & Folium Perillae & HB-1-FP & $\begin{array}{l}\text { Anguo, Hebei } \\
\text { province }\end{array}$ & Perilla frutescens & MG731094.1 & Perilla frutescens \\
\hline & Herba Taraxaci & HB-1-HT & $\begin{array}{l}\text { Anguo, Hebei } \\
\text { province }\end{array}$ & $\begin{array}{l}\text { Taraxacum mongoli- } \\
\quad \text { cum }\end{array}$ & AY548210.1 & $\begin{array}{l}\text { Taraxacum mongoli- } \\
\text { cum }\end{array}$ \\
\hline \multirow[t]{5}{*}{ CD-2-20171127 } & Flos Trollii & HB-1-FT & $\begin{array}{l}\text { Anguo, Hebei } \\
\text { province }\end{array}$ & Trollius chinensis & KC004044.1 & Trollius chinensis \\
\hline & $\begin{array}{l}\text { Radix Puerariae } \\
\text { Lobatae }\end{array}$ & CD-2-RPL & $\begin{array}{l}\text { Chengdu, Sichuan } \\
\text { province }\end{array}$ & Pueraria thomsonii & MG236579.1 & Pueraria thomsonii \\
\hline & Folium Isatidis & CD-2-FI & $\begin{array}{l}\text { Chengdu, Sichuan } \\
\text { province }\end{array}$ & Isatis indigotica & MG730905.1 & Isatis indigotica \\
\hline & Folium Perillae & CD-2-FP & $\begin{array}{l}\text { Chengdu, Sichuan } \\
\text { province }\end{array}$ & Perilla frutescens & KT210247.1 & Perilla frutescens \\
\hline & Herba Taraxaci & CD-2-HT & $\begin{array}{l}\text { Chengdu, Sichuan } \\
\text { province }\end{array}$ & $\begin{array}{l}\text { Taraxacum mongoli- } \\
\quad \text { cum }\end{array}$ & AY548210.1 & $\begin{array}{l}\text { Taraxacum mongoli- } \\
\text { cum }\end{array}$ \\
\hline
\end{tabular}


Table 1 (continued)

\begin{tabular}{|c|c|c|c|c|c|c|}
\hline ID & Crude drug & Sample number & Place of purchase & $\begin{array}{l}\text { Morphological } \\
\text { identification }\end{array}$ & $\begin{array}{l}\text { Genenbank } \\
\text { registration } \\
\text { number }\end{array}$ & $\begin{array}{l}\text { Molecular identifica- } \\
\text { tion }\end{array}$ \\
\hline \multirow[t]{5}{*}{ GD-1-20171202 } & Flos Trollii & HB-1-FT & $\begin{array}{l}\text { Anguo, Hebei } \\
\text { province }\end{array}$ & Trollius chinensis & КC004044.1 & Trollius chinensis \\
\hline & $\begin{array}{l}\text { Radix Puerariae } \\
\text { Lobatae }\end{array}$ & GD-1-RPL & $\begin{array}{l}\text { Guangzhou, Guang- } \\
\text { dong province }\end{array}$ & Pueraria thomsonii & MG236579.1 & Pueraria thomsonii \\
\hline & Folium Isatidis & GD-1-FI & $\begin{array}{l}\text { Guangzhou, Guang- } \\
\text { dong province }\end{array}$ & Isatis indigotica & MG730905.1 & Isatis indigotica \\
\hline & Folium Perillae & GD-1-FP & $\begin{array}{l}\text { Guangzhou, Guang- } \\
\text { dong province }\end{array}$ & Perilla frutescens & MG731094.1 & Perilla frutescens \\
\hline & Herba Taraxaci & GD-1-HT & $\begin{array}{l}\text { Guangzhou, Guang- } \\
\text { dong province }\end{array}$ & $\begin{array}{l}\text { Taraxacum mongoli- } \\
\quad \text { cum }\end{array}$ & AY548210.1 & $\begin{array}{l}\text { Taraxacum mongoli- } \\
\quad \text { cum }\end{array}$ \\
\hline \multirow[t]{5}{*}{ HF-1-20171219 } & Flos Trollii & HF-1-FT & $\begin{array}{l}\text { Hefei, Anhui prov- } \\
\text { ince }\end{array}$ & Trollius chinensis & KC004044.1 & Trollius chinensis \\
\hline & $\begin{array}{l}\text { Radix Puerariae } \\
\text { Lobatae }\end{array}$ & HF-1-RPL & $\begin{array}{l}\text { Hefei, Anhui prov- } \\
\text { ince }\end{array}$ & Pueraria thomsonii & MG236579.1 & Pueraria thomsonii \\
\hline & Folium Isatidis & HF-1-FI & $\begin{array}{l}\text { Hefei, Anhui prov- } \\
\text { ince }\end{array}$ & Isatis indigotica & MG730905.1 & Isatis indigotica \\
\hline & Folium Perillae & HF-1-FP & $\begin{array}{l}\text { Hefei, Anhui prov- } \\
\text { ince }\end{array}$ & Perilla frutescens & MG731094.1 & Perilla frutescens \\
\hline & Herba Taraxaci & HF-1-HT & $\begin{array}{l}\text { Hefei, Anhui prov- } \\
\text { ince }\end{array}$ & Taraxacum officinale & KY860926.1 & Taraxacum officinale \\
\hline \multirow[t]{5}{*}{ CD-3-20171127 } & Flos Trollii & CD-3-FT & $\begin{array}{l}\text { Chengdu, Sichuan } \\
\text { province }\end{array}$ & Trollius chinensis & КС004044.1 & Trollius chinensis \\
\hline & $\begin{array}{l}\text { Radix Puerariae } \\
\text { Lobatae }\end{array}$ & CD-3-RPL & $\begin{array}{l}\text { Chengdu, Sichuan } \\
\text { province }\end{array}$ & Pueraria thomsonii & MG236579.1 & Pueraria thomsonii \\
\hline & Folium Isatidis & CD-3-FI & $\begin{array}{l}\text { Chengdu, Sichuan } \\
\text { province }\end{array}$ & Isatis indigotica & MG730905.1 & Isatis indigotica \\
\hline & Folium Perillae & CD-3-FP & $\begin{array}{l}\text { Chengdu, Sichuan } \\
\text { province }\end{array}$ & Perilla frutescens & MG731094.1 & Perilla frutescens \\
\hline & Herba Taraxaci & CD-3-HT & $\begin{array}{l}\text { Chengdu, Sichuan } \\
\text { province }\end{array}$ & $\begin{array}{l}\text { Taraxacum mongoli- } \\
\text { cum }\end{array}$ & AY548210.1 & $\begin{array}{l}\text { Taraxacum mongoli- } \\
\text { cum }\end{array}$ \\
\hline
\end{tabular}

purchased from National Institutes for Food and Drug Control (Beijing, China). Trollioside [10], 3,4-dimethoxybenzoic acid [10], trollisin I [11], proglobeflowery acid [10], 2 "-O-(2'"'-methylbutanoyl)isoswertisin [11], tecomin [12], and $2 "-O$-(2'"-methylbutanoyl)vitexin [11] were isolated from Flos Trollii in our lab. The individual purity of each reference was confirmed over $98 \%$ according to HPLC analysis.

\section{Morphological and Molecular Identification of Crude Drugs}

\section{Morphological Identification}

The five crude drugs were morphologically identified by comparing their morphological characteristics including shape, color, odor, size, texture and sectional properties with those recorded in Pharmacopoeia of the People's Republic of China $[13,14]$.

\section{Molecular Identification}

The five crude drugs $(0.1 \mathrm{~g})$ were subject to total DNA extraction using DNA rapid extraction kit of broad spectra plant genome. The sequence of forward primer ITS2F was 5'-ATG CGATACTTGGTGTGAAT-3', while that of the reverse primer ITS3R was 5'-GACGCTTCTCCAGACTACAAT-3'. The reaction system of PCR included $12.5 \mu \mathrm{L} 2 \times$ Taq PCR Master Mix enzyme, $1.0 \mu \mathrm{L}$ of forward primer and $1.0 \mu \mathrm{L}$ of reverse primer $\left(5 \mu \mathrm{mol} \mathrm{L}^{-1}\right), 1.0 \mu \mathrm{L}$ of total DNA and $9.5 \mu \mathrm{L}$ of $\mathrm{ddH}_{2} \mathrm{O}$. The PCR amplification was carried out using the program compose of $94^{\circ} \mathrm{C}$ for $5 \mathrm{~min}, 94^{\circ} \mathrm{C}$ for $30 \mathrm{~s}, 56^{\circ} \mathrm{C}$ for $30 \mathrm{~s}$, and $72{ }^{\circ} \mathrm{C}$ for $45 \mathrm{~s}$ (40 recycles), then $72{ }^{\circ} \mathrm{C}$ for $10 \mathrm{~min}$ again. The resultant samples were stored at $4{ }^{\circ} \mathrm{C}$. The samples were sent to Beijing Bomaide Biotechnology Co., Ltd. for 
sequencing after test with $1 \%$ agarose gel electrophoresis. Contig Express 3.0 (Informax., Inc, USA) was used for the assembly and sequence checking. The checked ITS2 sequences were uploaded to the GenBank database for Basic Local Alignment Search Tool (BLAST) comparison to determine whether they were the target ones.

\section{Qualitative Analysis of JD by LC-QExactive-MS}

\section{Preparation of Test Samples}

In accordance with the proportion of the prescription, a quantity of five crude drugs was taken, and a volume of water was added to extract two times, each for $30 \mathrm{~min}$. The extract was filtered and combined, and then concentrated to each $1 \mathrm{~mL}$ containing $0.1 \mathrm{~g}$ of crude drug. The concentrate was stored at $-20{ }^{\circ} \mathrm{C}$, and centrifuged at $12,000 \mathrm{r} \mathrm{min}^{-1}$ for $10 \mathrm{~min}$ before use. The supernatant was taken as the test solution.

\section{Apparatus and Analytical Conditions}

Chromatographic separation was performed with a Waters BEH C $_{18}$ column $(100 \mathrm{~mm} \times 2.1 \mathrm{~mm}$ i.d.; $1.7 \mu \mathrm{m})$. Gradient elution was performed in 60 min using the mobile phase consisting of acetonitrile with formic acid $(0.1 \% \mathrm{v} / \mathrm{v})(\mathrm{A})$ and $0.1 \%$ $\mathrm{v} / \mathrm{v}$ aqueous formic acid (B) from 5 to $95 \% \mathrm{~A}$ at a flow rate of $0.2 \mathrm{~mL} \mathrm{~min}^{-1}$. The injection volume was $5 \mu \mathrm{L}$.

System used in positive and negative ion modes was coupled with heated electrospray source (HESI), and the spray voltages were $3.5 \mathrm{kV}$ for positive and $2.8 \mathrm{kV}$ for negative. The flow rate of sheath gas was 30 arbitrary units (a.u.), and that of auxiliary gas was 10 a.u.. Other conditions included capillary temperature of $320^{\circ} \mathrm{C}$ and resolution of 70,000 .

\section{Statistical Analysis}

In accordance with the precise molecular weight of the compound obtained from the total ion chromatogram (TIC) and the fragment ions generated in the characteristic mode, Xcalibur and CD 2.1 were used to calculate the possible composition (error less than $5 \mathrm{ppm}$ ). Then, based on the characteristic fragment ion information of compounds, the attribution information and the existing relevant composition reported, the possible structure was inferred. The compound designation referred to the ChemSpider database, the Pubmed database, the mzVault database, and the mzCloud database.

\section{Quantitative Analysis of 24 Components by LC-QTrap-MS}

\section{Apparatus and Analytical Conditions}

Chromatographic separation was performed with an ACQUITY UPLC HSS T3 column $(100 \mathrm{~mm} \times 2.1 \mathrm{~mm}$ i.d.; $1.8 \mu \mathrm{m})$. The mobile phase consisted of acetonitrile with formic acid $(0.1 \% \mathrm{v} / \mathrm{v})(\mathrm{A})$ and $0.1 \% \mathrm{v} / \mathrm{v}$ aqueous formic acid (B), and the flow rate was $0.2 \mathrm{~mL} \mathrm{~min}^{-1}$. Gradient elution was as follows: $0-1 \mathrm{~min}, 0 \% \mathrm{~A} ; 1-3 \mathrm{~min}, 0-20 \%$ A; 3-11 min, 20\% A; 11-14 min, 20-35\% A; 14-17 min, $35-70 \%$ A; $17-19$ min, $70-100 \%$ A; $19-21 \mathrm{~min}, 100 \% \mathrm{~A}$; 21-21.1 min, $100-0 \% \mathrm{~A}$. The injection volume was $5 \mu \mathrm{L}$.

System used in negative ion mode was coupled with electrospray ionization source (ESI). The ionspray voltage (IS) was $4500 \mathrm{~V}$, and ionization temperature (TEM) was $500{ }^{\circ} \mathrm{C}$. The nebulizer gas (GS1) and heater gas (GS2) were 50 and 40 psi, respectively. For MRM mode, the precursor ion, product ion, de-clustering potential (DP), entrance potential (EP), collision energy (CE) and collision cell exit potential (CXP) of the 24 measured components are shown in Table 2. Total ion MRM chromatogram of mixed references and samples are shown in Fig. 1.

\section{Preparation of Reference Solutions}

Stock solutions of 24 references (each $1.0 \mathrm{mg} \mathrm{mL}^{-1}$ ) were individually prepared by dissolving accurately weighed reference compounds in methanol. A mixed reference solution containing all 24 reference compounds was prepared and serially diluted with methanol to appropriate concentrations to produce working solutions for quantitative analysis $(0.5,1,2,5,10,20,50,100,200,500$, and $1000 \mathrm{ng}$ $\mathrm{mL}^{-1}$ ). The solutions were stored at $-20{ }^{\circ} \mathrm{C}$ before use.

\section{Results}

\section{Morphological and Molecular Identification of Crude Drugs}

The results of morphological identification were consistent with those of molecular identification (Table 1), which showed that 34 samples out of the total of 40 samples of crude drugs used were from the original plant collected in Chinese pharmacopoeia and the remaining six samples including five samples of Radix Puerariae Lobatae and 1 sample of Folium Isatidis were from the alternative original plants Pueraria thomsonii and Polygonum tinctorium, 
Table 2 Optimized structure parameters of 24 components in JD

\begin{tabular}{|c|c|c|c|c|c|c|c|}
\hline ID & Analyte & Precursor ion & Product ion & DP (volts) & EP (volts) & $\mathrm{CE}$ (volts) & CXP (volts) \\
\hline 1 & Genistin & 431.2 & 269.1 & -145.0 & -8.0 & -25.0 & -18.0 \\
\hline 2 & Apigenin & 269.0 & 117.1 & -140.0 & -10.0 & -43.0 & -8.0 \\
\hline 3 & Trollioside & 397.2 & 235.1 & -145.0 & -10.0 & -20.0 & -17.0 \\
\hline 4 & 3'-Methoxy puerarin & 445.2 & 325.1 & -170.0 & -5.0 & -33.0 & -20.0 \\
\hline 5 & Daidzin & 415.1 & 252.2 & -170.0 & -5.0 & -36.0 & -15.0 \\
\hline 6 & Kaempferol & 285.0 & 211.0 & -170.0 & -10.0 & -40.0 & -15.0 \\
\hline 7 & Caffeic acid & 179.0 & 135.0 & -100.0 & -4.0 & -22.0 & -8.0 \\
\hline 8 & Puerarin & 415.1 & 295.1 & -150.0 & -6.0 & -32.0 & -19.0 \\
\hline 9 & Rutin & 609.2 & 300.0 & -220.0 & -10.0 & -50.0 & -20.0 \\
\hline 10 & Scutellarin & 461.1 & 285.2 & -125.0 & -10.0 & -28.0 & -20.0 \\
\hline 11 & Vitexin & 431.2 & 311.1 & -160.0 & -4.0 & -31.0 & -20.0 \\
\hline 12 & Rosmarinic acid & 359.1 & 161.0 & -110.0 & -4.0 & -20.0 & -12.0 \\
\hline 13 & Ferulic acid & 193.0 & 134.0 & -110.0 & -5.0 & -22.0 & -9.0 \\
\hline 14 & Orientin & 447.2 & 327.1 & -140.0 & -7.0 & -30.0 & -21.0 \\
\hline 15 & 3,4-Dimethoxybenzoic acid & 181.0 & 137.1 & -130.0 & -9.0 & -16.0 & -9.0 \\
\hline 16 & 3'-Hydroxy puerarin & 431.2 & 311.1 & -165.0 & -6.0 & -32.0 & -20.0 \\
\hline 17 & Trollisin I & 545.2 & 443.2 & -180.0 & -10.0 & -40.0 & -9.0 \\
\hline 18 & $2^{\prime \prime}-O-\beta$-L-Galactopyranosylorientin & 609.2 & 327.1 & -170.0 & -10.0 & -42.0 & -20.0 \\
\hline 19 & Proglobeflowery acid & 235.0 & 191.1 & -130.0 & -9.0 & -20.0 & -14.0 \\
\hline 20 & $2^{\prime \prime}-O$-(2'"-Methylbutanoyl)isoswertisin & 529.2 & 427.2 & -140.0 & -6.0 & -37.0 & -12.0 \\
\hline 21 & Tecomin & 343.2 & 181.0 & -105.0 & -9.0 & -15.0 & -13.0 \\
\hline 22 & $2 "-O-\left(2^{\prime \prime \prime}-\right.$ Methylbutanoyl)vitexin & 515.2 & 413.2 & -145.0 & -10.0 & -21.0 & -9.0 \\
\hline 23 & Cynaroside & 447.2 & 285.1 & -170.0 & -10.0 & -35.0 & -17.0 \\
\hline 24 & Indirubin & 261.0 & 157.1 & -160.0 & -10.0 & -40.0 & -11.0 \\
\hline
\end{tabular}
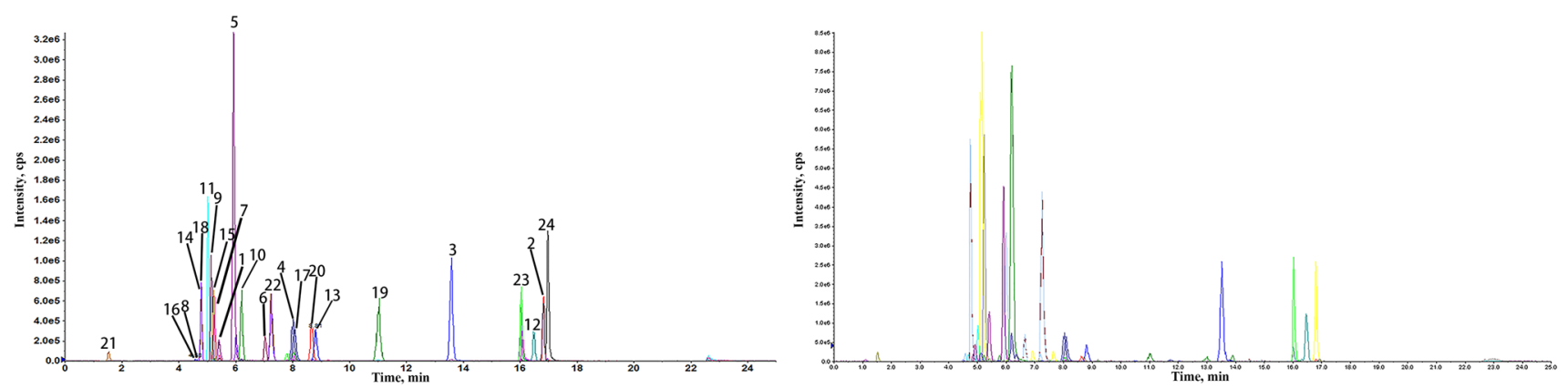

Fig. 1 Total ion MRM chromatogram of mixed references (left) and samples (right)

respectively. All identification results were confirmed by Professor Rufeng Wang.

\section{Qualitative Analysis of JD}

The TIC of JD analyzed by LC-QExactive-MS system is shown in Fig. 2. Eighty-nine compounds were deduced and their structures are provided in Tables 3, 4 and Fig. 3, respectively.

\section{Validation of Quantitative Analysis}

\section{Linearity, Lower Limit of Detection (LLOD), And lower Limit of Quantification (LLOQ)}

For the calibration curve established, different concentrations of reference solution were taken for LC-MS/MS analysis in triplicate. Calibration curves for 24 analytes were generated by plotting the average peak areas versus the corresponding concentrations. Good linearity $(R \leq 0.9919)$ in the tested concentration ranges of the analytes except 

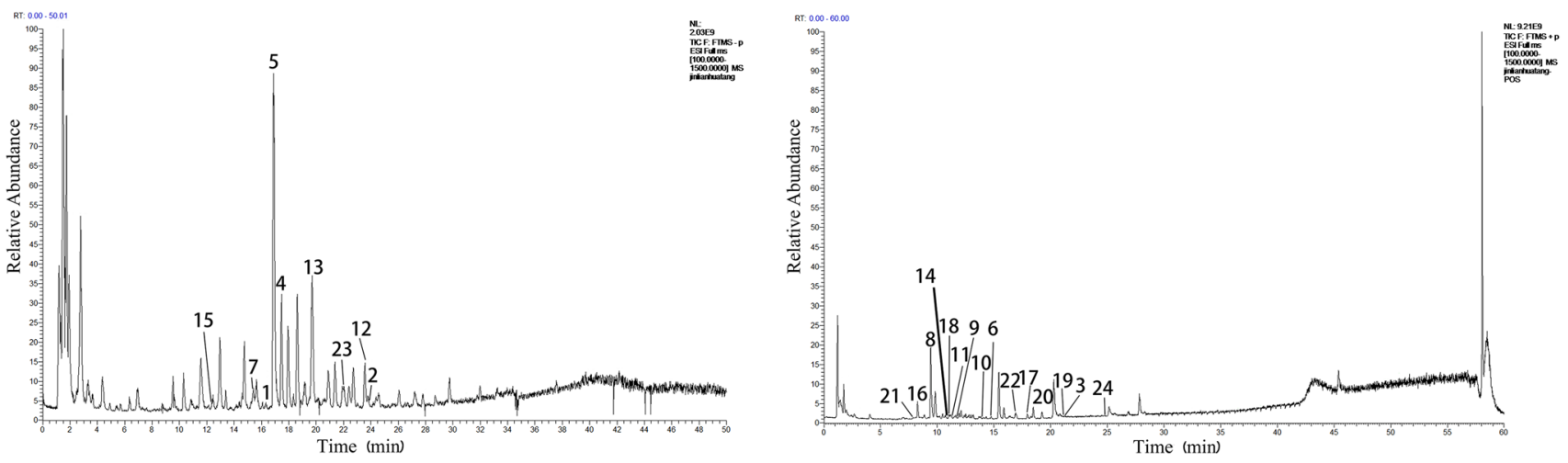

Fig. 2 Total ion chromatogram (TIC) of JD in negative mode (left) and positive mode (right)

indirubin was observed. The minimum concentration of linearity solution was selected and then diluted to series of solution, respectively, and the values calculated at signal to noise $(S / N)$ ratios of 3 and 10 were considered as LLOD and LLOQ, respectively (Table 5).

\section{Precision, Repeatability and Stability}

The precision of the developed method was validated by determining intra-day and inter-day variations and was expressed in the form of relative standard deviations (RSD). Six replicates were analyzed within a day for the intra-day variation assessment, and the experiments were duplicated on three consecutive days for the inter-day variation assessment. The RSD values of the intra-day and inter-day variations were in the ranges of $2.17-4.79 \%$ and $0.91-4.95 \%$, respectively. The repeatability was tested using six test solutions prepared according to the same method, and the RSD values were in the range of $1.20-4.95 \%$. Stability was evaluated by analyzing the sample solutions at room temperature at $0,2,4,8,12$, and $24 \mathrm{~h}$, and the RSD values for 24 references were all less than $4.95 \%$. Thus, the developed method exhibited good precision, repeatability, and stability (Table 6).

\section{Recovery}

The recovery test was conducted with three concentration levels (low, medium, and high) of the mixed references added to the known amounts of samples. The resulting samples were extracted and analyzed by the proposed method. The whole process was repeated, and the content of each analyte was determined by the corresponding calibration curve. The percentage recoveries were calculated according to the equation: (total detected amount - original amount)/ added amount $\times 100 \%$. The results showed that the recoveries were within the range of $80.35-119.68 \%$, and the RSD value variations were in the range of $0.19-5.08 \%$. Thus, the developed method exhibited good accuracy (Table 7).

\section{Sample Analysis}

The validated UPLC-MS/MS analytical method was applied to simultaneous quantification of 24 components in eight batches of JD. The contents of the compounds $(n=3)$ were calculated with an external standard method based on their respective calibration curves. The results are listed in Table 8.

\section{Discussion}

Unlike individual crude drugs, decoction of Chinese medicine contains diversified compounds. These compounds are difficult to be characterized by the common analytical procedure because of their complexity. We established a qualitative and quantitative method for analysis of the main components in JD by UHPLC-MS/MS for the first time. The qualitative analysis was performed using LC-QExactiveMS under high resolution and high sensitivity. Based on the resultant precise molecular weight, and mass spectrometry fragmentation of the compounds, the composition of JD has been comprehensively explained. The quantitative analysis was conducted by LC-QTrap-MS. This method is fast and efficient, and does not require complete separation of the chromatographic peaks of multiple components. The precision, repeatability, stability and recovery for the assigned compounds excluding indirubin are in well compliance with the measurement requirements. And the LLOQ is as low as $0.05-4.67 \mathrm{ng} \mathrm{mL}^{-1}$, which can be used for related studies with low component content.

Qualitative and quantitative analyses of JD prepared from eight batches of crude drugs obtained from various places of China were carried out by the above methods. The qualitative results showed that JD mainly contains 89 compounds, 


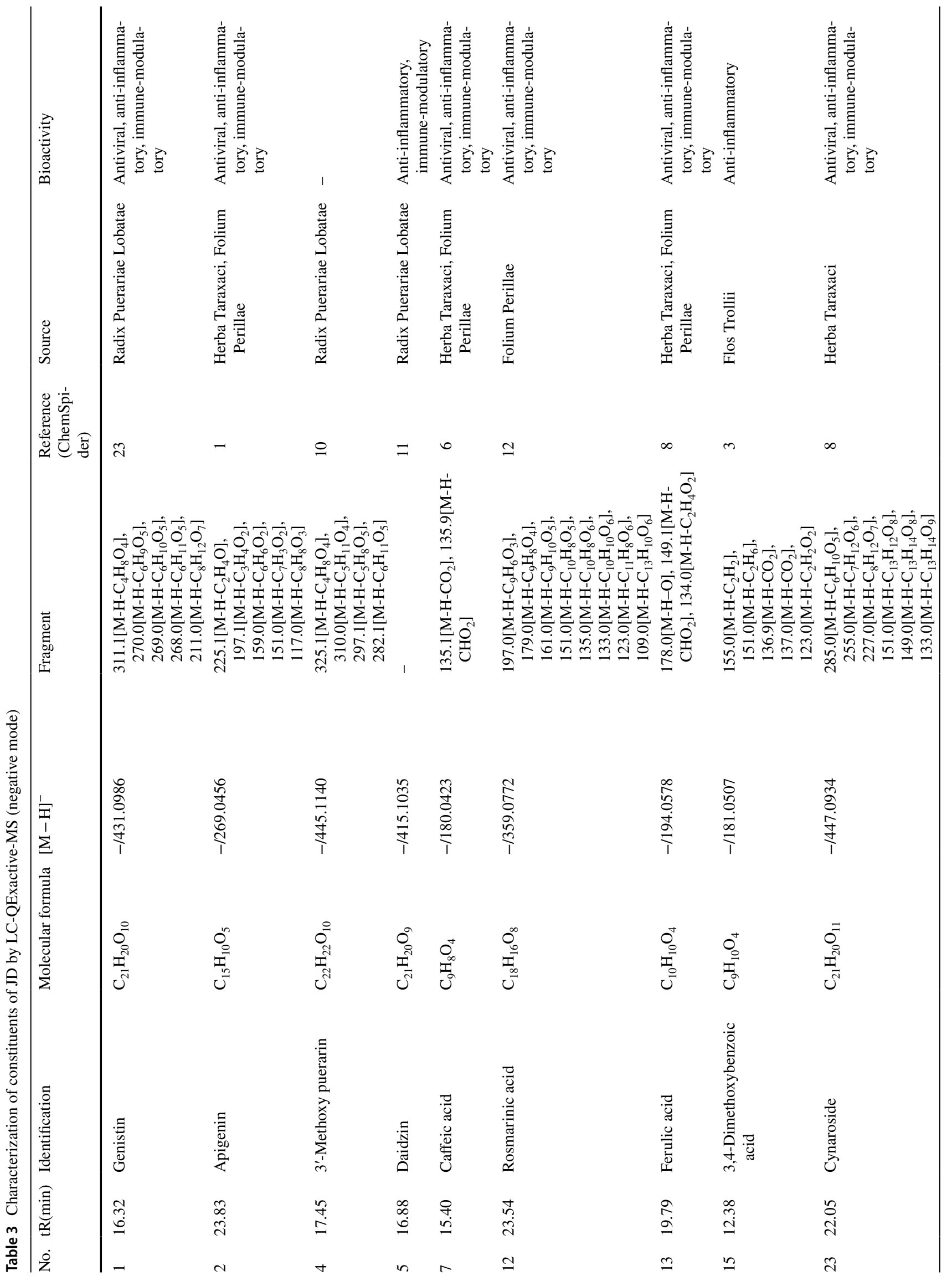




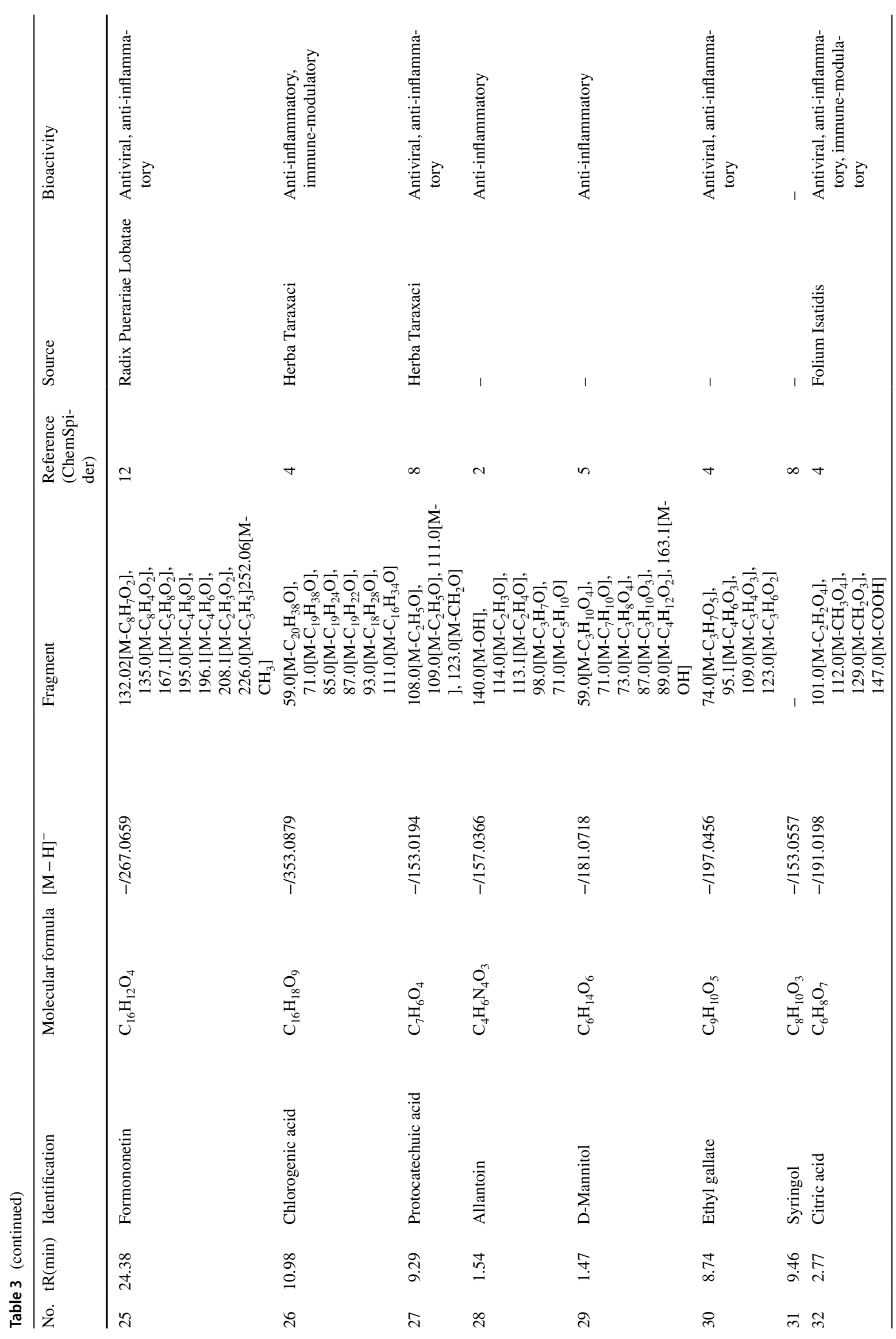




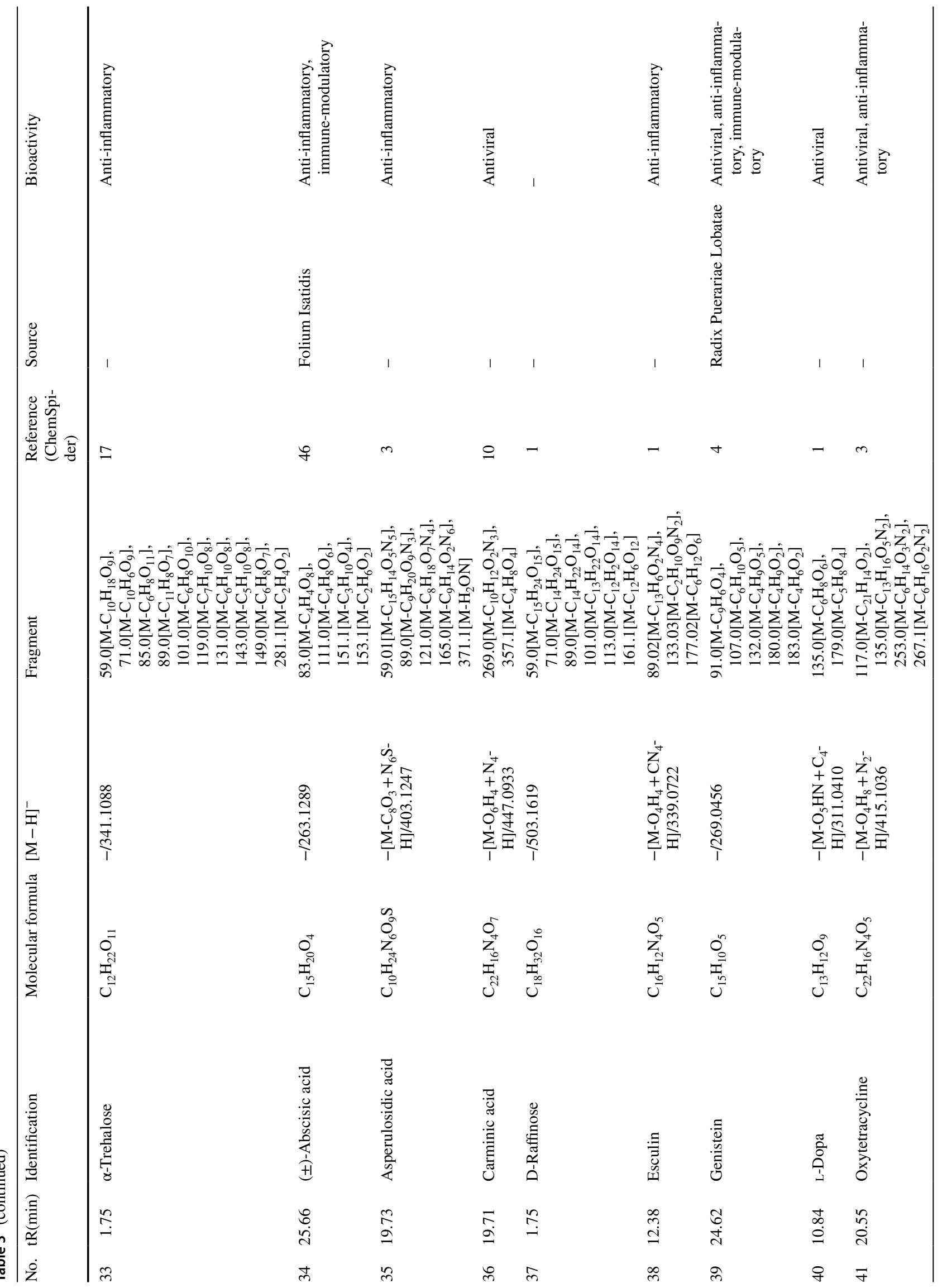




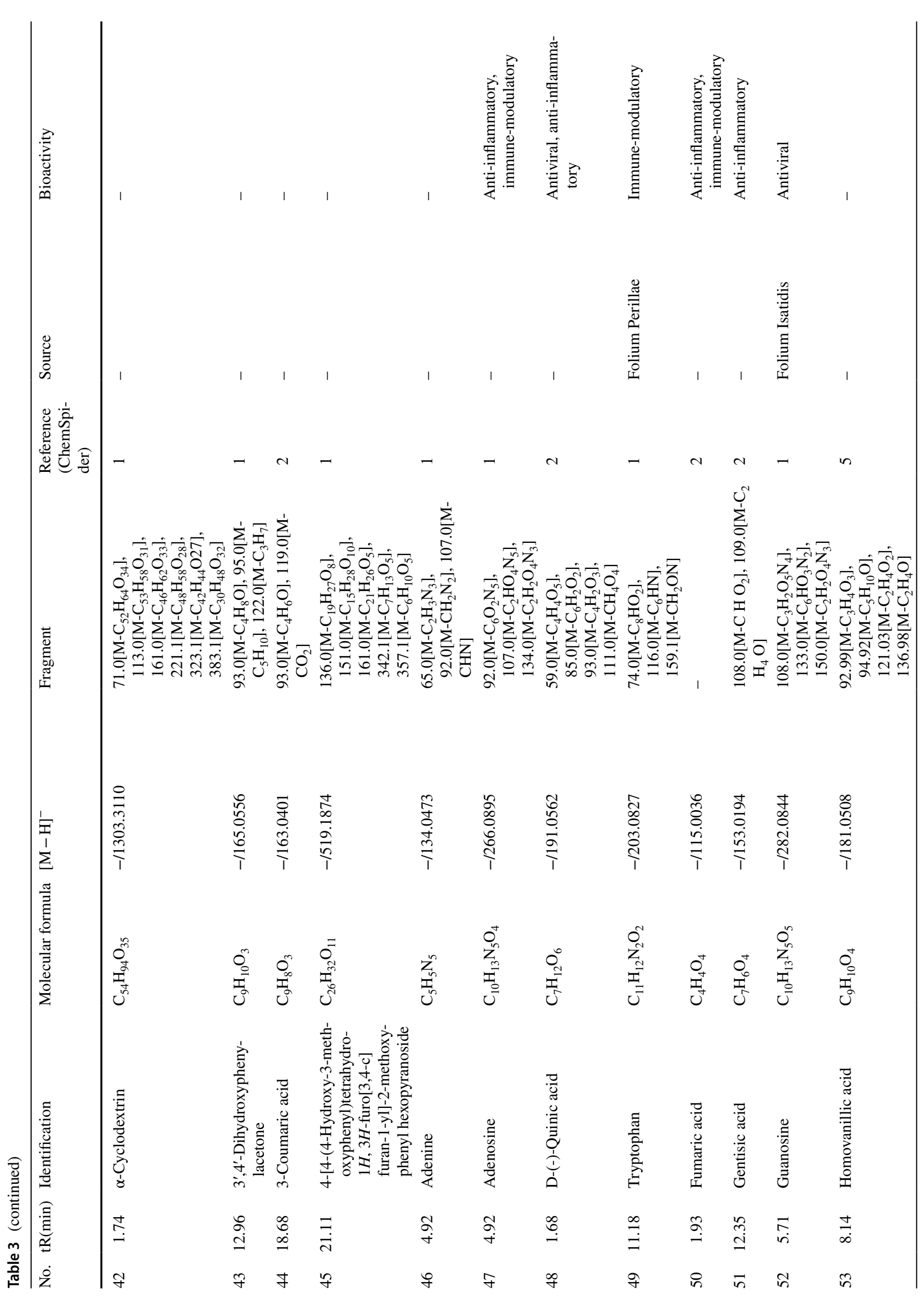




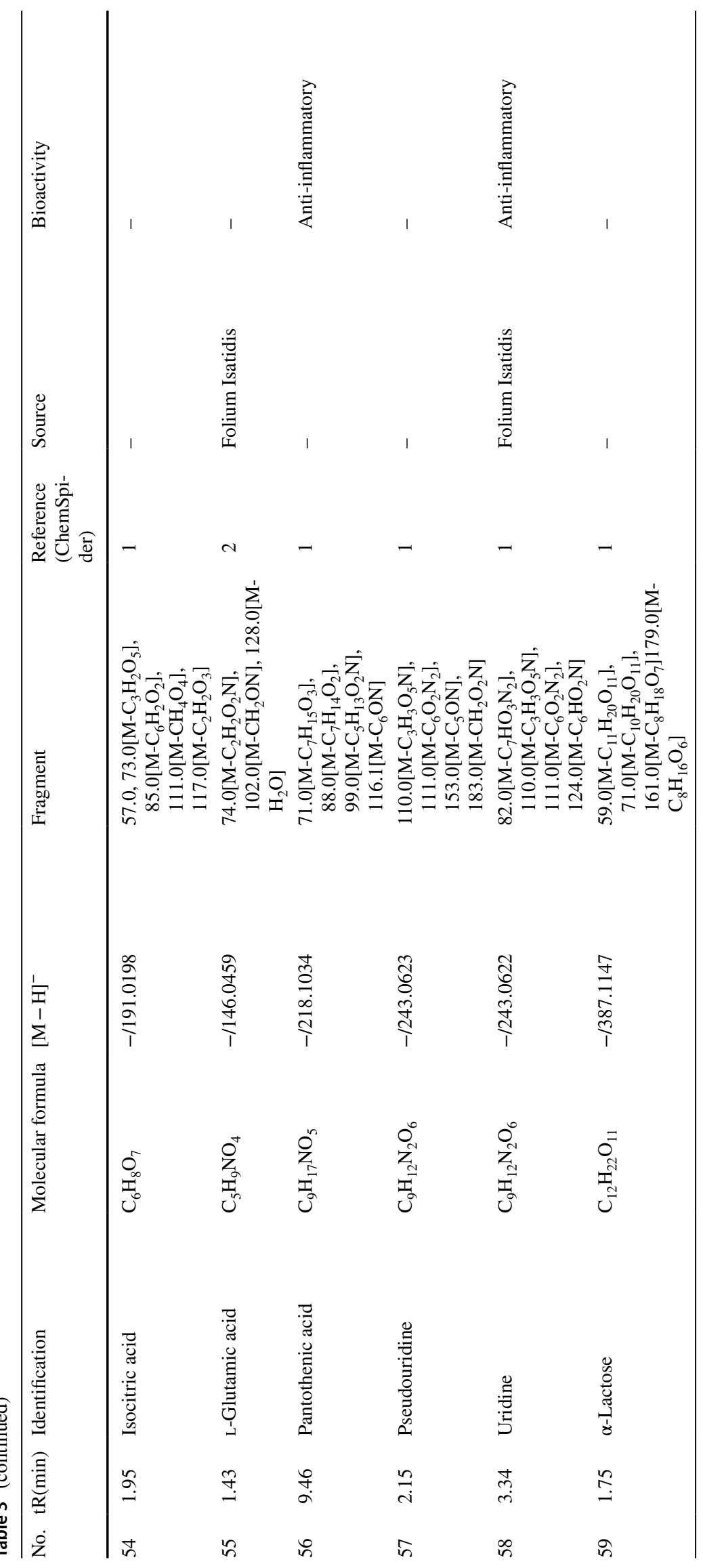




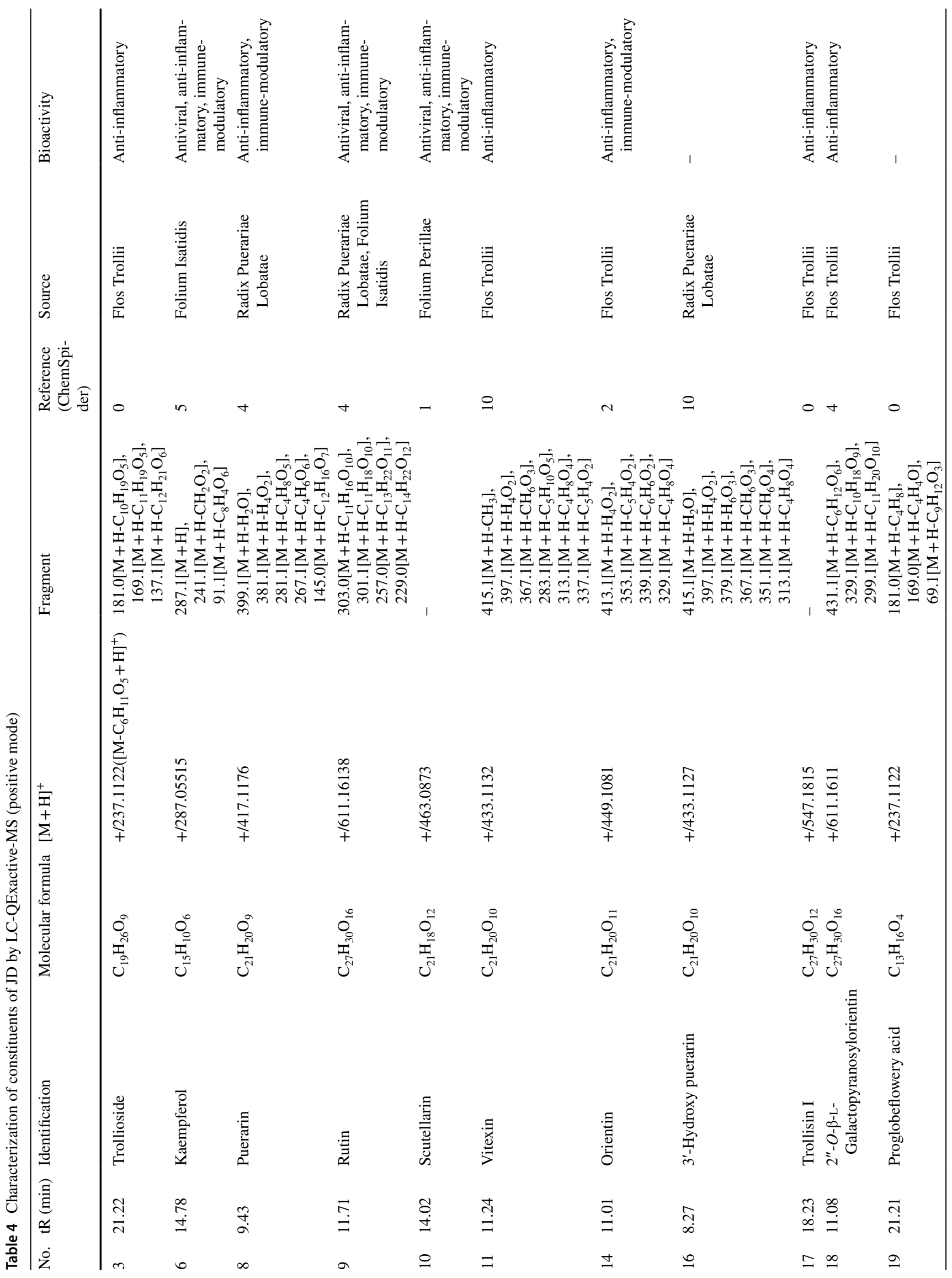




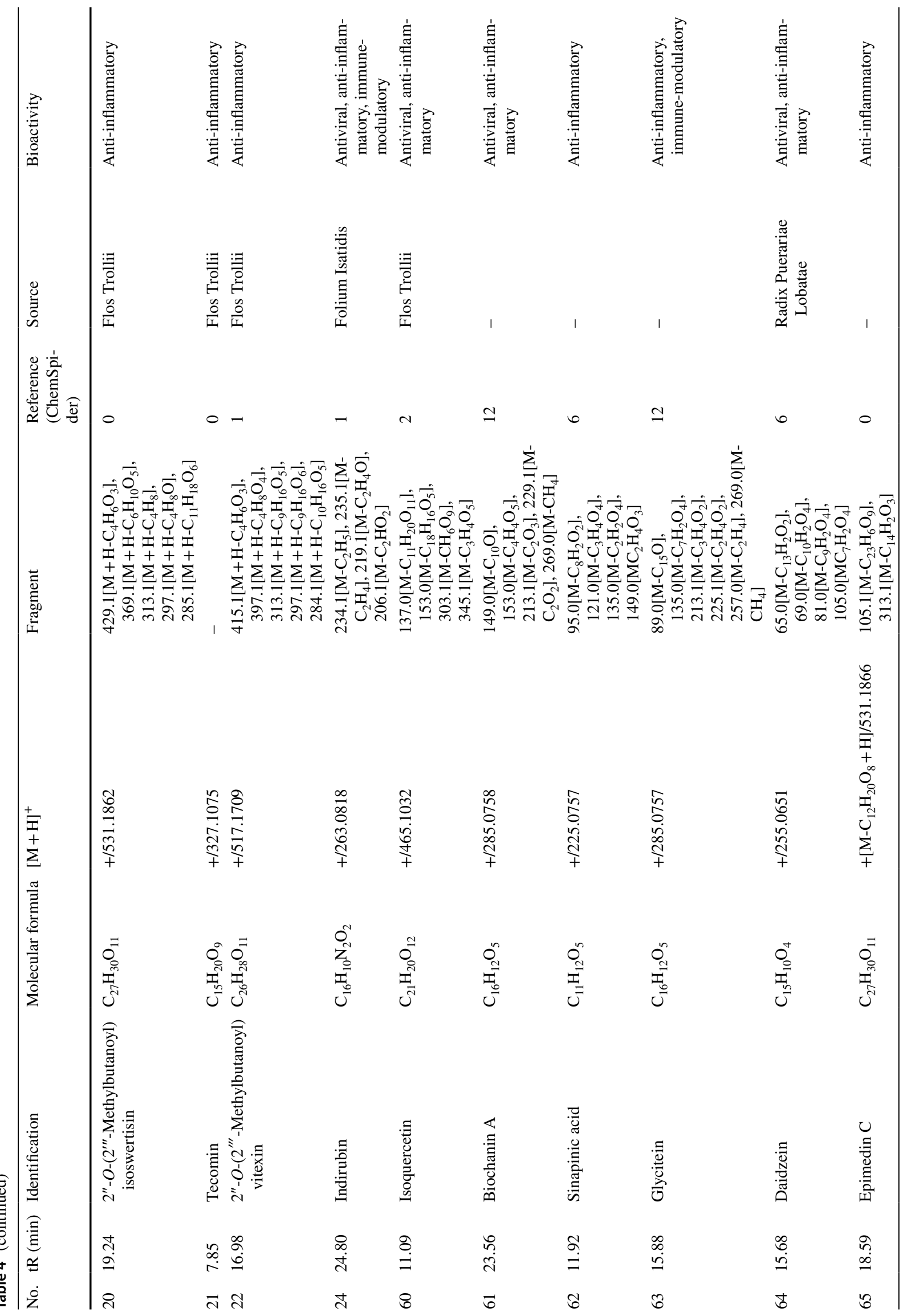




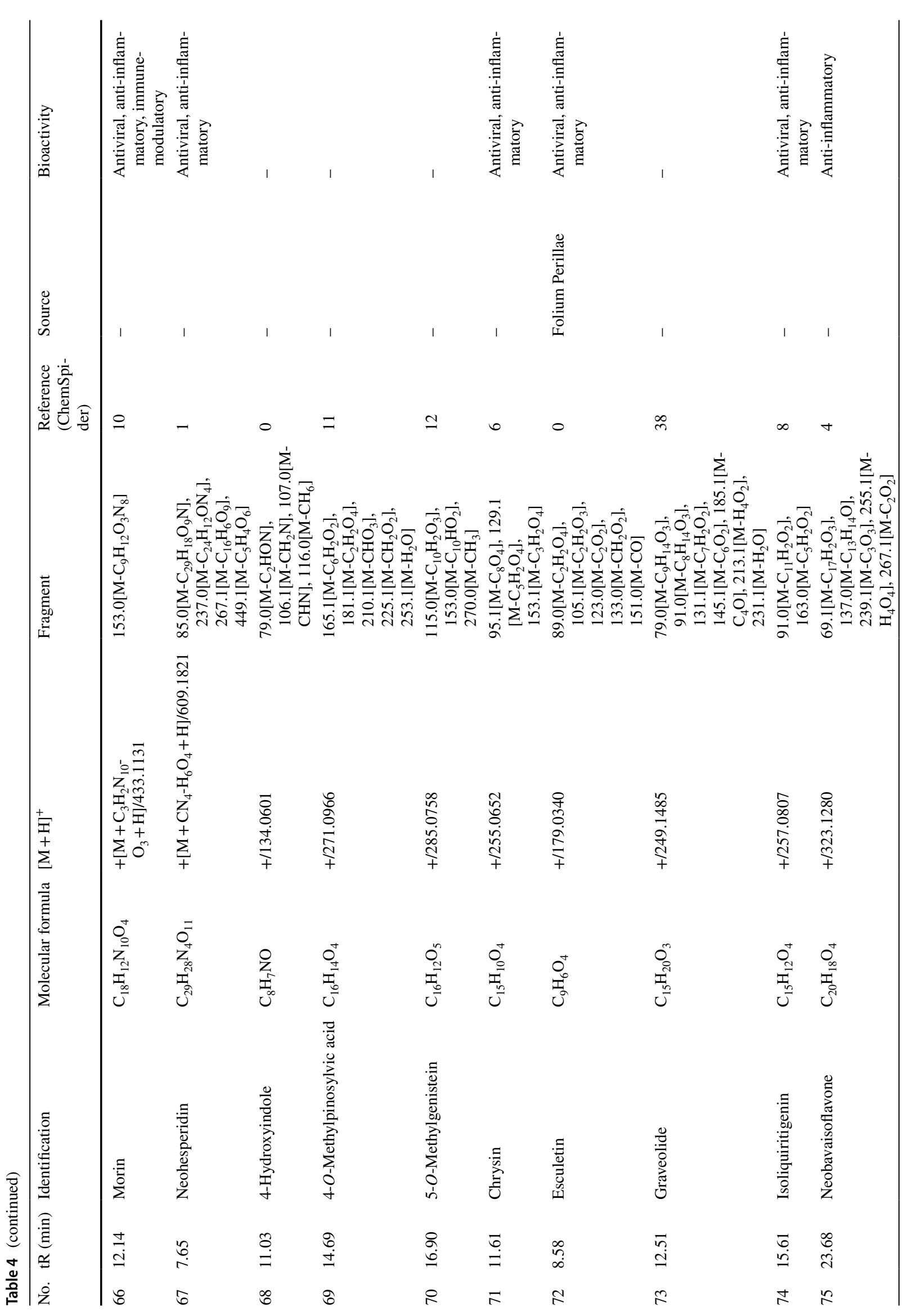




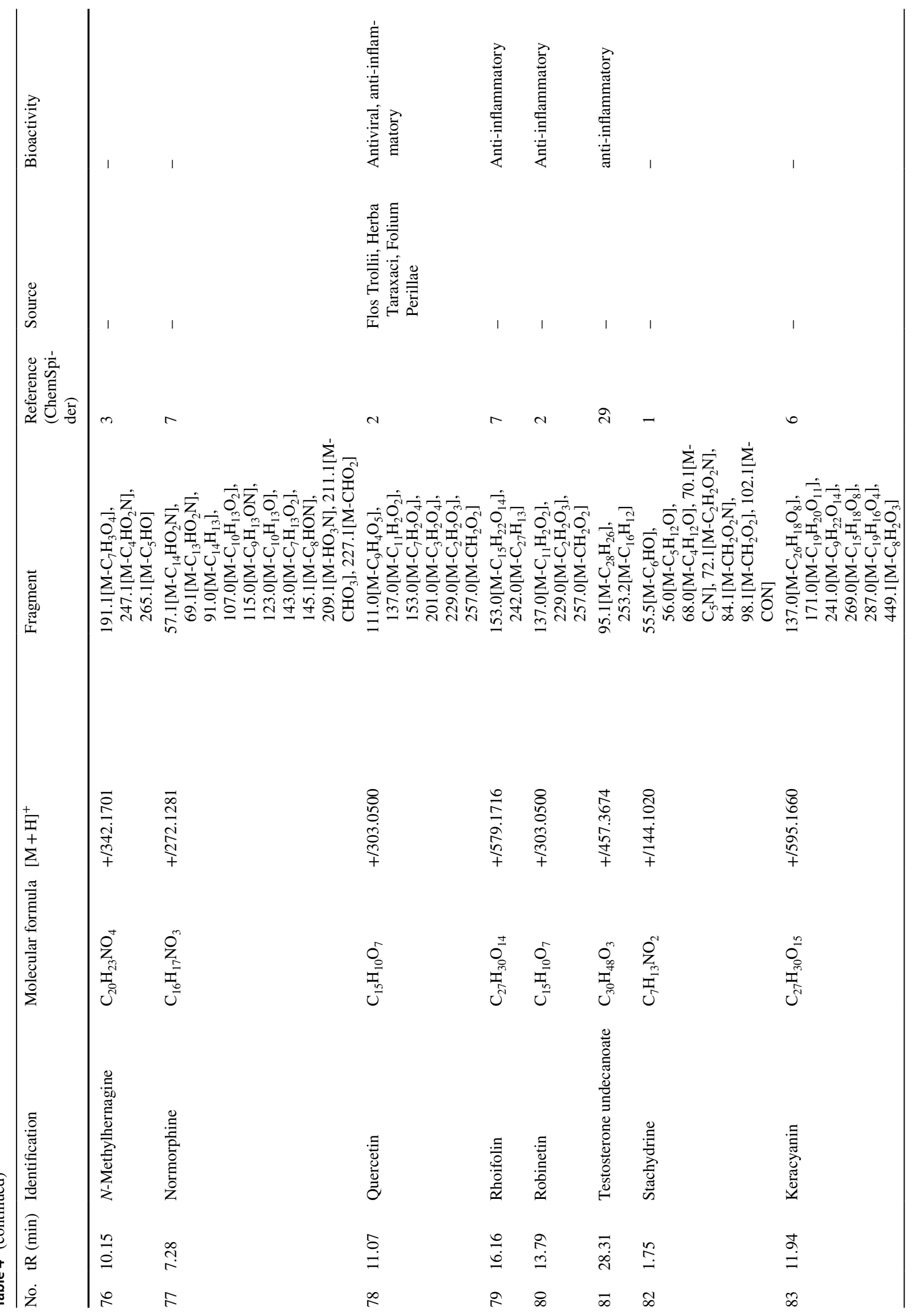




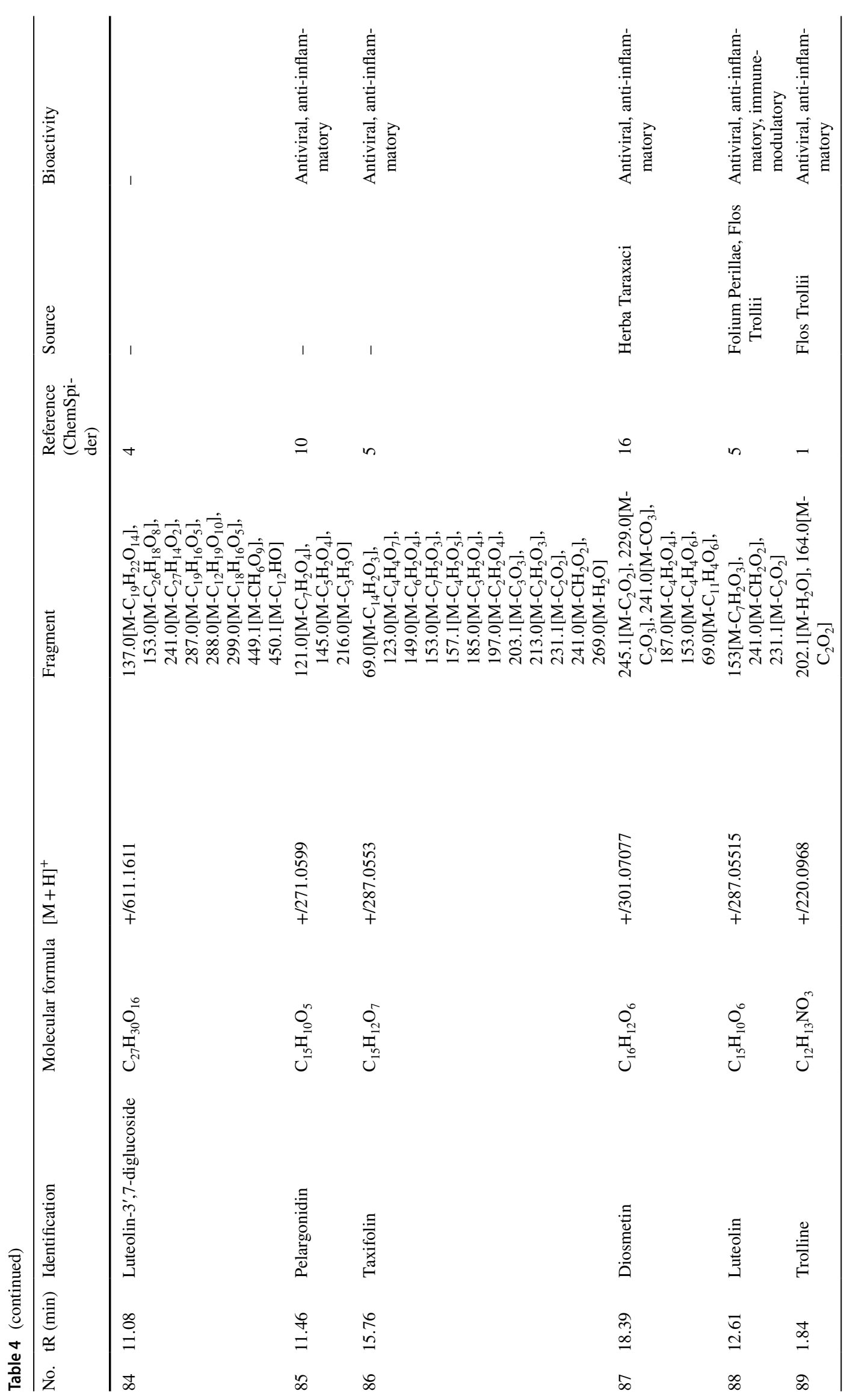




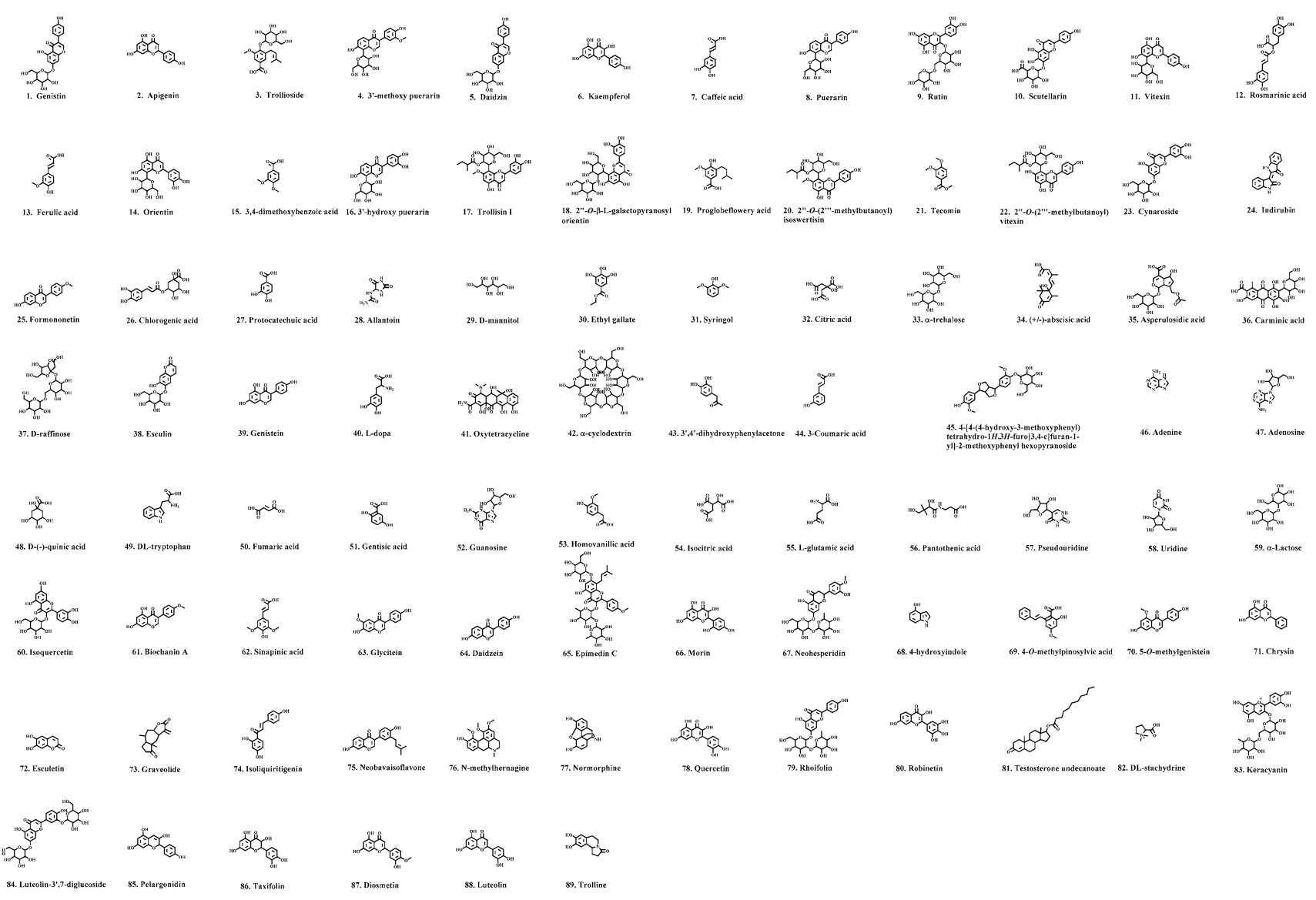

Fig. 3 The structures of 89 assigned compounds

and most of them belong to flavonoids, phenolic acids and alkaloids. After these compounds were screened on the basis of their bioactivities related to the efficacy of JD, 24 compounds including 16 flavonoids, 7 phenolic acids and 1 alkaloid were selected to perform the quantitative analysis. The results showed that the compounds whose contents in the decoction were above $100 \mu \mathrm{g} \mathrm{g}^{-1}$ crude drug included orientin, $2^{\prime \prime}-O$ - $\beta$-L-galactopyranosylorientin, puerarin, trollisin I, rosmarinic acid, 2"-O-(2'"-methylbutanoyl) isoswertisin, daidzin, scutellarin, 3'-methoxy puerarin, vitexin, 3'-hydroxy puerarin, 2"-O-(2'"-methylbutanoyl) vitexin, kaempferol, caffeic acid, 3,4-dimethoxybenzoic acid, and cynaroside in descending order. These components are mainly from Flos Trollii, Radix Puerariae Lobatae, and Folium Perillae [15-17], and have related bioactivities such as antiviral, antibacterial and anti-inflammatory effects [12, 18-37]. Therefore, these compounds can be considered as the major components of JD.

It was found through statistical analysis that the contents of the 24 components differ greatly in JD prepared from different batches of crude drugs. This might be because the crude drugs of different batches were different in origin, growing environments, preparation process, storage, etc., which resulted in uneven drug quality. For example, based on the results of morphological and molecular identifications, some samples of Radix Puerariae Lobatae used in the experiments were from the roots of $P$. thomsonii rather than Pueraria lobata. Although the Chinese pharmacopoeia 2005 edition onward has excluded $P$. thomsonii as the original plant of Puerariae Lobatae, the crude drugs from both original plants are still used indiscriminately in the clinical practice. Thus, the content of puerarin in JD decoction prepared with the roots of Pueraria lobata was significantly higher than that prepared with the roots of $P$. thomsonii. Our results were also consistent with the findings reported previously [38]. Even for crude drugs of the same origin, their quality is also different due to the diversified growing environment, preparation process and storage condition. The difference of components in the crude drugs and decoctions inevitably affects the consistency of efficacy. The quality control of the chemical components is an important means to guarantee the pharmacological effects of crude drugs and the decoctions [39]. Therefore, the genuine regional crude drugs should be used as much as possible, and the preparation process and storage condition should also be strictly standardized. In addition, indirubin was detected as one of 
Table 5 Calibration curves, correlation coefficient $(R)$, linear range, lower limit of detection (LLOD), and lower limit of quantification (LLOQ) of 24 analytes

\begin{tabular}{|c|c|c|c|c|c|c|}
\hline ID & Analyte & Calibration curve & $R$ & $\begin{array}{l}\text { Linear range } \\
\left(\mathrm{ng} \mathrm{mL}^{-1}\right)\end{array}$ & $\begin{array}{l}\text { LLOD (ng } \\
\mathrm{mL}^{-1} \text { ) }\end{array}$ & $\begin{array}{l}\text { LLOQ } \\
\left(\mathrm{ng} \mathrm{mL}^{-1}\right)\end{array}$ \\
\hline 1 & Genistin & $Y=2.06 \times 10^{4} x+5.93 \times 10^{3}$ & 0.9989 & $1-500$ & 0.02 & 0.06 \\
\hline 2 & Apigenin & $Y=3.14 \times 10^{4} x-1.91 \times 10^{4}$ & 0.9988 & $1-1000$ & 0.08 & 0.27 \\
\hline 3 & Trollioside & $Y=4.7 \times 10^{4} x+2.7 \times 10^{4}$ & 0.9985 & $1-500$ & 0.02 & 0.08 \\
\hline 4 & 3'-Methoxy puerarin & $Y=2.82 \times 10^{4} x+6.44 \times 10^{3}$ & 0.9984 & $1-500$ & 0.02 & 0.07 \\
\hline 5 & Daidzin & $Y=1.08 \times 10^{4} x+6.35 \times 10^{3}$ & 0.9986 & $1-500$ & 0.05 & 0.15 \\
\hline 6 & Kaempferol & $Y=2.88 \times 10^{3} x+425$ & 0.9979 & $2-500$ & 0.46 & 1.55 \\
\hline 7 & Caffeic acid & $Y=1.6 \times 10^{5} x+8.44 \times 10^{4}$ & 0.9990 & $1-100$ & 0.22 & 0.73 \\
\hline 8 & Puerarin & $Y=4.25 \times 10^{4} x+2.91 \times 10^{3}$ & 0.9994 & $1-200$ & 0.04 & 0.12 \\
\hline 9 & Rutin & $Y=1.2 \times 10^{4} x+429$ & 0.9977 & $0.5-1000$ & 0.06 & 0.20 \\
\hline 10 & Scutellarin & $Y=2.34 \times 10^{4} x+2.32 \times 10^{3}$ & 0.9987 & $0.5-500$ & 0.08 & 0.27 \\
\hline 11 & Vitexin & $Y=4.11 \times 10^{4} x+1.63 \times 10^{3}$ & 0.9989 & $0.5-1000$ & 0.02 & 0.05 \\
\hline 12 & Rosmarinic acid & $Y=6.38 \times 10^{4} x-9.96 \times 10^{3}$ & 0.9987 & $0.5-500$ & 0.03 & 0.11 \\
\hline 13 & Ferulic acid & $Y=2.43 \times 10^{4} x+8.91 \times 10^{3}$ & 0.9977 & $1-500$ & 0.14 & 0.45 \\
\hline 14 & Orientin & $Y=3.66 \times 10^{4} x+9.17 \times 10^{4}$ & 0.9955 & $5-500$ & 0.04 & 0.13 \\
\hline 15 & 3,4-Dimethoxybenzoic acid & $Y=3 \times 10^{3} x+4.58 \times 10^{3}$ & 0.9985 & $5-500$ & 1.40 & 4.67 \\
\hline 16 & 3'-Hydroxy puerarin & $Y=2.49 \times 10^{4} x+1.06 \times 10^{4}$ & 0.9961 & $0.5-1000$ & 0.03 & 0.09 \\
\hline 17 & Trollisin I & $Y=3.66 \times 10^{4} x-1.77 \times 10^{6}$ & 0.9919 & $50-1000$ & 0.07 & 0.22 \\
\hline 18 & $2^{\prime \prime}-O-\beta-\mathrm{L}-$ Galactopyranosylorientin & $Y=1.4 \times 10^{4} x-5.99 \times 10^{3}$ & 0.9996 & $1-500$ & 0.03 & 0.09 \\
\hline 19 & Proglobeflowery acid & $Y=1.28 \times 10^{3} x-367$ & 0.9992 & $1-1000$ & 0.20 & 0.68 \\
\hline 20 & $2^{\prime \prime}-O-\left(2^{\prime \prime \prime}-\right.$ Methylbutanoyl)isoswertisin & $Y=3.55 \times 10^{4} x-9.19 \times 10^{4}$ & 0.9987 & $5-500$ & 0.05 & 0.17 \\
\hline 21 & Tecomin & $Y=1.32 \times 10^{3} x-197$ & 0.9981 & $5-500$ & 0.96 & 3.19 \\
\hline 22 & $2^{\prime \prime}-O$-(2'"-Methylbutanoyl)vitexin & $Y=3.28 \times 10^{4} x-5.12 \times 10^{3}$ & 0.9941 & $0.5-500$ & 0.04 & 0.13 \\
\hline 23 & Cynaroside & $Y=3.4 \times 10^{4} x+1.48 \times 10^{3}$ & 0.9980 & $0.5-500$ & 0.04 & 0.12 \\
\hline 24 & Indirubin & $Y=630 x-1.77 \times 10^{3}$ & 0.9875 & $10-1000$ & 1.50 & 5.27 \\
\hline
\end{tabular}

the main components of Folium Isatidis in qualitative analysis; however, it could not be quantified due to its poor ion response. In the methodological test of quantitative analysis, the precision, stability, and repeatability results for indirubin were not qualified. Consequently, the quantitative results for indirubin are for reference only, which may be related to the poor stability of this compound. It has been reported that the content of this compound decreased significantly with the increase of standing time under natural light and room temperature, and slightly reduced even under refrigeration conditions [40].

\section{Conclusions}

The qualitative and quantitative analysis methods established in this study are suitable for the analysis and monitoring of the main components in JD. The 16 compounds determined based on the qualitative and quantitative results are the major components of the decoction. This study provides a scientific basis for the determination of pharmacodynamic substances of JD, and lays a foundation for the quality control research of the decoction. 
Table 6 Precision, repeatability and stability of 24 analytes $(n=6)$

\begin{tabular}{|c|c|c|c|c|c|c|c|c|c|}
\hline \multirow[t]{2}{*}{ ID } & \multirow[t]{2}{*}{ Analyte } & \multicolumn{4}{|l|}{ Precision } & \multicolumn{2}{|l|}{ Repeatability } & \multicolumn{2}{|l|}{ Stability } \\
\hline & & $\begin{array}{l}\text { Concentration (ng } \\
\mathrm{mL}^{-1} \text { ) }\end{array}$ & $\begin{array}{l}\text { Intra-day } \\
\text { RSD }(\%)\end{array}$ & $\begin{array}{l}\text { Concentration (ng } \\
\mathrm{mL}^{-1} \text { ) }\end{array}$ & $\begin{array}{l}\text { Inter-day } \\
\text { RSD (\%) }\end{array}$ & $\begin{array}{l}\text { Concentration ( } \mu \mathrm{g} \\
\left.\mathrm{g}^{-1}\right)\end{array}$ & RSD (\%) & $\begin{array}{l}\text { Concentration }(\mu \mathrm{g} \\
\left.\mathrm{g}^{-1}\right)\end{array}$ & $\operatorname{RSD}(\%)$ \\
\hline 1 & Genistin & $100.88 \pm 4.46$ & 4.42 & $64.93 \pm 1.66$ & 2.56 & $134.92 \pm 2.13$ & 1.58 & $144.19 \pm 6.72$ & 4.66 \\
\hline 2 & Apigenin & $99.83 \pm 4.09$ & 4.10 & $35.55 \pm 1.47$ & 4.14 & $2.79 \pm 0.09$ & 3.12 & $4.08 \pm 0.12$ & 2.92 \\
\hline 3 & Trollioside & $100.51 \pm 3.98$ & 3.96 & $75.53 \pm 3.40$ & 4.50 & $16.46 \pm 0.28$ & 1.73 & $17.77 \pm 0.57$ & 3.18 \\
\hline 4 & 3'-Methoxy puerarin & $41.62 \pm 1.27$ & 3.04 & $77.33 \pm 2.85$ & 3.69 & $560.99 \pm 15.76$ & 2.81 & $572.52 \pm 26.74$ & 4.67 \\
\hline 5 & Daidzin & $108.69 \pm 3.30$ & 3.04 & $73.62 \pm 3.20$ & 4.35 & $1146.50 \pm 36.00$ & 3.14 & $1220.13 \pm 36.36$ & 2.98 \\
\hline 6 & Kaempferol & $104.91 \pm 4.07$ & 3.88 & $59.37 \pm 2.84$ & 4.78 & $30.08 \pm 0.56$ & 1.87 & $31.55 \pm 1.56$ & 4.95 \\
\hline 7 & Caffeic acid & $84.94 \pm 2.14$ & 2.52 & $71.82 \pm 1.22$ & 1.70 & $4.57 \pm 0.19$ & 4.18 & $7.77 \pm 0.10$ & 1.26 \\
\hline 8 & Puerarin & $87.06 \pm 2.85$ & 3.27 & $79.57 \pm 3.94$ & 4.95 & $1317.35 \pm 15.81$ & 1.20 & $1284.37 \pm 30.82$ & 2.40 \\
\hline 9 & Rutin & $124.18 \pm 5.77$ & 4.65 & $70.18 \pm 2.65$ & 3.78 & $4.62 \pm 0.13$ & 2.89 & $4.09 \pm 0.16$ & 3.86 \\
\hline 10 & Scutellarin & $91.71 \pm 4.19$ & 4.57 & $65.94 \pm 1.15$ & 1.75 & $36.68 \pm 1.02$ & 2.77 & $37.25 \pm 1.08$ & 2.91 \\
\hline 11 & Vitexin & $96.75 \pm 4.24$ & 4.39 & $75.52 \pm 2.79$ & 3.69 & $425.43 \pm 20.72$ & 4.87 & $447.91 \pm 19.17$ & 4.28 \\
\hline 12 & Rosmarinic acid & $93.92 \pm 4.06$ & 4.32 & $86.58 \pm 2.77$ & 3.20 & $5.00 \pm 0.18$ & 3.59 & $5.29 \pm 0.09$ & 1.69 \\
\hline 13 & Ferulic acid & $91.79 \pm 2.07$ & 2.25 & $84.57 \pm 3.86$ & 4.56 & $3.66 \pm 0.18$ & 4.95 & $3.43 \pm 0.09$ & 2.54 \\
\hline 14 & Orientin & $107.86 \pm 5.17$ & 4.79 & $58.38 \pm 1.05$ & 1.79 & $1163.50 \pm 40.26$ & 3.46 & $1185.66 \pm 40.55$ & 3.42 \\
\hline 15 & 3,4-Dimethoxybenzoic acid & $94.66 \pm 2.92$ & 3.09 & $147.08 \pm 5.87$ & 3.99 & $87.22 \pm 3.39$ & 3.89 & $87.76 \pm 3.15$ & 3.59 \\
\hline 16 & 3'-Hydroxy puerarin & $118.44 \pm 4.82$ & 4.07 & $78.20 \pm 2.90$ & 3.71 & $103.26 \pm 4.09$ & 3.96 & $106.83 \pm 3.57$ & 3.34 \\
\hline 17 & Trollisin I & $103.71 \pm 2.44$ & 2.35 & $14.86 \pm 0.53$ & 3.60 & $105.76 \pm 2.87$ & 2.71 & $150.69 \pm 5.06$ & 3.36 \\
\hline 18 & $\begin{array}{l}2 "-O-\beta-\mathrm{L}- \\
\quad \text { Galactopyranosylorientin }\end{array}$ & $89.99 \pm 3.37$ & 3.74 & $57.46 \pm 1.03$ & 1.80 & $203.07 \pm 4.45$ & 2.19 & $200.71 \pm 4.03$ & 2.01 \\
\hline 19 & Proglobeflowery acid & $81.13 \pm 1.76$ & 2.17 & $35.33 \pm 0.32$ & 0.91 & $13.78 \pm 0.52$ & 3.77 & $14.90 \pm 0.54$ & 3.63 \\
\hline 20 & $\begin{array}{l}2^{\prime \prime}-O-\left(2^{\prime \prime \prime}-\text { Methylbutanoyl }\right) \\
\text { isoswertisin }\end{array}$ & $84.03 \pm 3.86$ & 4.59 & $14.11 \pm 0.70$ & 4.94 & $183.67 \pm 5.29$ & 2.88 & $2.70 \pm 0.01$ & 0.18 \\
\hline 21 & Tecomin & $89.54 \pm 3.95$ & 4.41 & $43.27 \pm 2.05$ & 4.73 & $162.24 \pm 6.78$ & 4.18 & $163.73 \pm 7.94$ & 4.85 \\
\hline 22 & $\begin{array}{l}2^{\prime \prime}-O-\left(2^{\prime \prime \prime}-\text { Methylbutanoyl }\right) \\
\text { vitexin }\end{array}$ & $102.21 \pm 4.11$ & 4.02 & $32.22 \pm 1.42$ & 4.40 & $123.50 \pm 5.52$ & 4.47 & $154.40 \pm 7.04$ & 4.56 \\
\hline 23 & Cynaroside & $113.11 \pm 4.26$ & 3.77 & $60.04 \pm 0.64$ & 1.07 & $73.37 \pm 2.37$ & 3.23 & $76.69 \pm 1.40$ & 1.82 \\
\hline 24 & Indirubin & $51.26 \pm 2.88$ & 5.62 & $22.22 \pm 1.56$ & 7.02 & $6.91 \pm 0.90$ & 13.02 & $17.44 \pm 2.02$ & 11.58 \\
\hline
\end{tabular}


Table 7 Method recoveries for 23 analytes $(n=3)$

\begin{tabular}{|c|c|c|c|c|c|c|}
\hline ID & Analyte & Initial $(\mu \mathrm{g})$ & Spiked $(\mu \mathrm{g})$ & Detected $(\mu \mathrm{g})$ & Recovery (\%) & $\operatorname{RSD}(\%)$ \\
\hline \multirow[t]{3}{*}{1} & \multirow[t]{3}{*}{ Genistin } & \multirow[t]{3}{*}{79.10} & 92.49 & $157.47 \pm 3.86$ & 84.73 & 2.45 \\
\hline & & & 92.25 & $159.5 \pm 6.36$ & 87.15 & 3.99 \\
\hline & & & 46.48 & $119.96 \pm 4.39$ & 87.90 & 3.66 \\
\hline \multirow[t]{3}{*}{2} & \multirow[t]{3}{*}{ Apigenin } & \multirow[t]{3}{*}{6.27} & 8.27 & $13.40 \pm 0.31$ & 86.22 & 2.35 \\
\hline & & & 6.06 & $13.30 \pm 0.48$ & 112.04 & 3.62 \\
\hline & & & 4.40 & $11.26 \pm 0.55$ & 113.29 & 4.86 \\
\hline \multirow[t]{3}{*}{3} & \multirow[t]{3}{*}{ Trollioside } & \multirow[t]{3}{*}{21.73} & 33.97 & $49.07 \pm 2.22$ & 80.48 & 4.52 \\
\hline & & & 22.53 & $43.12 \pm 1.66$ & 94.91 & 3.86 \\
\hline & & & 10.90 & $32.03 \pm 1.46$ & 94.52 & 4.57 \\
\hline \multirow[t]{3}{*}{4} & \multirow[t]{3}{*}{ 3'-Methoxy puerarin } & \multirow[t]{3}{*}{1726.70} & 2042.37 & $3822.73 \pm 105.13$ & 102.63 & 2.75 \\
\hline & & & 1616.70 & $3380.00 \pm 55.77$ & 102.27 & 1.65 \\
\hline & & & 945.82 & $2608.83 \pm 90.79$ & 93.27 & 3.48 \\
\hline \multirow[t]{3}{*}{5} & \multirow[t]{3}{*}{ Daidzin } & \multirow[t]{3}{*}{2533.00} & 3743.00 & $6057.00 \pm 261.66$ & 94.15 & 4.32 \\
\hline & & & 3150.13 & $5775.24 \pm 198.09$ & 102.92 & 3.43 \\
\hline & & & 1431.61 & $3984.522 \pm 137.47$ & 101.39 & 3.45 \\
\hline \multirow[t]{3}{*}{6} & \multirow[t]{3}{*}{ Kaempferol } & \multirow[t]{3}{*}{149.90} & 199.23 & $366.94 \pm 16.81$ & 108.94 & 4.58 \\
\hline & & & 148.00 & $293.00 \pm 4.25$ & 96.69 & 1.45 \\
\hline & & & 48.80 & $197.40 \pm 6.53$ & 97.32 & 3.31 \\
\hline \multirow[t]{3}{*}{7} & \multirow[t]{3}{*}{ Caffeic acid } & \multirow[t]{3}{*}{208.60} & 302.08 & $502.54 \pm 22.01$ & 97.31 & 4.38 \\
\hline & & & 164.40 & $354.74 \pm 16.11$ & 88.89 & 4.54 \\
\hline & & & 112.97 & $343.12 \pm 11.43$ & 119.07 & 3.33 \\
\hline 8 & Puerarin & 8983.33 & $12,733.33$ & $24,150.00 \pm 799.37$ & 119.11 & 3.31 \\
\hline & & & $11,248.06$ & $20,969.17 \pm 993.94$ & 106.56 & 4.74 \\
\hline & & & 3593.33 & $12,050.00 \pm 506.10$ & 85.34 & 4.20 \\
\hline 9 & Rutin & 8.76 & 12.10 & $20.56 \pm 0.73$ & 97.49 & 3.57 \\
\hline & & & 11.10 & $20.92 \pm 0.34$ & 109.55 & 1.64 \\
\hline & & & 5.43 & $13.85 \pm 0.31$ & 93.80 & 2.27 \\
\hline 10 & Scutellarin & 163.90 & 186.02 & $374.61 \pm 13.79$ & 113.27 & 3.68 \\
\hline & & & 166.90 & $298.00 \pm 0.57$ & 80.35 & 0.19 \\
\hline & & & 89.59 & $264.67 \pm 11.17$ & 112.48 & 4.22 \\
\hline 11 & Vitexin & 1206.67 & 1711.45 & $2844.81 \pm 126.59$ & 95.72 & 4.45 \\
\hline & & & 1466.67 & $2466.67 \pm 81.15$ & 85.91 & 3.29 \\
\hline & & & 809.33 & $1999.22 \pm 92.76$ & 97.93 & 4.64 \\
\hline 12 & Rosmarinic acid & 273.00 & 438.84 & $740.54 \pm 28.51$ & 106.54 & 3.85 \\
\hline & & & 290.30 & $539.16 \pm 18.06$ & 91.68 & 3.35 \\
\hline & & & 268.00 & $547.0 \pm 1.42$ & 102.24 & 0.26 \\
\hline 13 & Ferulic acid & 22.03 & 50.52 & $63.98 \pm 2.10$ & 83.04 & 3.28 \\
\hline & & & 30.20 & $46.38 \pm 2.00$ & 80.63 & 4.31 \\
\hline & & & 16.52 & $40.66 \pm 1.66$ & 112.82 & 4.09 \\
\hline 14 & Orientin & 5033.33 & 6290.00 & $10,592.00 \pm 433.21$ & 88.85 & 4.09 \\
\hline & & & 5421.90 & $11,385.99 \pm 561.33$ & 117.17 & 4.93 \\
\hline & & & 1589.47 & $6483.64 \pm 243.14$ & 91.24 & 3.75 \\
\hline 15 & 3,4-Dimethoxybenzoic acid & 1926.67 & 2377.63 & $4542.85 \pm 131.29$ & 110.03 & 2.89 \\
\hline & & & 1393.43 & $3154.21 \pm 147.30$ & 88.10 & 4.67 \\
\hline & & & 576.00 & $2616.00 \pm 132.89$ & 119.68 & 5.08 \\
\hline 16 & 3'-Hydroxy puerarin & 1206.67 & 1712.92 & $2851.39 \pm 127.17$ & 96.02 & 4.46 \\
\hline & & & 1466.67 & $2466.67 \pm 81.15$ & 85.91 & 3.29 \\
\hline & & & 809.33 & $1999.22 \pm 92.76$ & 97.93 & 4.64 \\
\hline
\end{tabular}


Table 7 (continued)

\begin{tabular}{|c|c|c|c|c|c|c|}
\hline ID & Analyte & Initial $(\mu \mathrm{g})$ & Spiked $(\mu \mathrm{g})$ & Detected $(\mu \mathrm{g})$ & Recovery (\%) & $\operatorname{RSD}(\%)$ \\
\hline \multirow[t]{3}{*}{17} & \multirow[t]{3}{*}{ Trollisin I } & \multirow[t]{3}{*}{273.00} & 333.20 & $636.25 \pm 25.00$ & 109.02 & 3.93 \\
\hline & & & 251.00 & $562.00 \pm 28.27$ & 115.14 & 5.03 \\
\hline & & & 197.47 & $460.04 \pm 6.72$ & 94.72 & 1.46 \\
\hline \multirow[t]{3}{*}{18} & \multirow[t]{3}{*}{$2 "-O-\beta$-L-Galactopyranosylorientin } & \multirow[t]{3}{*}{531.33} & 656.7 & $1148.23 \pm 45.13$ & 93.94 & 3.93 \\
\hline & & & 594.33 & $1175.00 \pm 44.06$ & 108.30 & 3.75 \\
\hline & & & 176.66 & $737.10 \pm 33.61$ & 116.48 & 4.56 \\
\hline \multirow[t]{3}{*}{19} & \multirow[t]{3}{*}{ Proglobeflowery acid } & \multirow[t]{3}{*}{24.17} & 32.02 & $49.92 \pm 2.39$ & 80.42 & 4.79 \\
\hline & & & 22.93 & $45.64 \pm 2.17$ & 93.63 & 4.75 \\
\hline & & & 6.80 & $32.13 \pm 1.13$ & 117.05 & 3.51 \\
\hline \multirow[t]{3}{*}{20} & \multirow[t]{3}{*}{$2^{\prime \prime}-O$-(2'"'-Methylbutanoyl)isoswertisin } & \multirow[t]{3}{*}{428.00} & 557.45 & $968.85 \pm 38.08$ & 97.02 & 3.93 \\
\hline & & & 351.00 & $816.00 \pm 19.82$ & 110.54 & 2.43 \\
\hline & & & 253.99 & $662.09 \pm 16.88$ & 92.16 & 2.55 \\
\hline \multirow[t]{3}{*}{21} & \multirow[t]{3}{*}{ Tecomin } & \multirow[t]{3}{*}{300.67} & 376.67 & $616.00 \pm 25.93$ & 83.72 & 4.21 \\
\hline & & & 365.30 & $611.76 \pm 21.41$ & 85.16 & 3.50 \\
\hline & & & 153.55 & $466.78 \pm 17.32$ & 108.18 & 3.71 \\
\hline \multirow[t]{3}{*}{22} & \multirow[t]{3}{*}{$2^{\prime \prime}-O-\left(2^{\prime \prime \prime}-\right.$ Methylbutanoyl $)$ vitexin } & \multirow[t]{3}{*}{221.00} & 278.57 & $488.57 \pm 23.65$ & 96.05 & 4.84 \\
\hline & & & 232.00 & $450.00 \pm 16.97$ & 98.71 & 3.77 \\
\hline & & & 118.80 & $348.03 \pm 9.43$ & 106.93 & 2.71 \\
\hline \multirow[t]{3}{*}{23} & \multirow[t]{3}{*}{ Cynaroside } & \multirow[t]{3}{*}{119.80} & 157.60 & $283.00 \pm 9.91$ & 103.55 & 3.50 \\
\hline & & & 155.84 & $292.20 \pm 9.73$ & 110.63 & 3.33 \\
\hline & & & 102.39 & $202.48 \pm 8.30$ & 80.75 & 4.10 \\
\hline
\end{tabular}




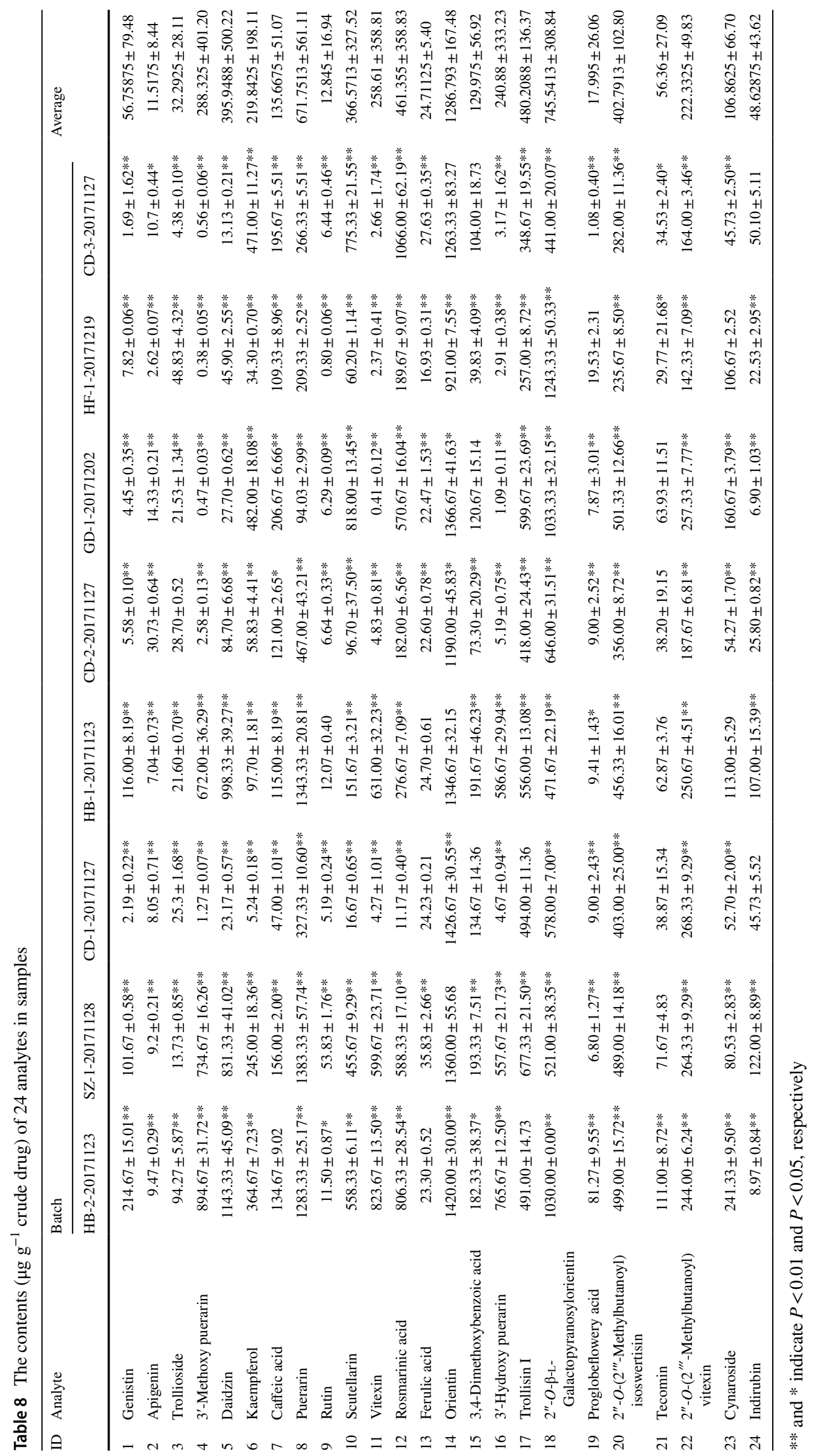


Acknowledgements We would like to express our thanks to Ms. Lili $\mathrm{Li}$, Meng Chen, Siqi Liu and Jingya Ai, and Mr Yuesheng Pang for their technical support in the experiments.

Funding This work was supported by Beijing Municipal Natural Science Foundation No. 7172129.

\section{Compliance with ethical standards}

Conflict of interest The authors declare that they have no conflict of interest.

Ethical approval This article does not contain any studies with human participants or animals performed by any of the authors.

\section{References}

1. Ge ZY, Tong J, Wang XY, Na JJ, Zou L, Lu GF (2015) Analysis of TCM about influenza. J Liaoning Univ Tradit Chin Med 17:77-79

2. Yu XP, Fu HT (2006) Recent research of mechanism of immunoregulation on Chinese medicine anti-influenza-virus actions. Liaoning J Tradit Chin Med 33:1044-1046

3. Hao Y, Shi LQ, Duan LY, Wu J, Ren JG, Hao QY (2006) Effect of Xuanfei Toujie prescription on lung inflammation and inflammation-related cytokines in mouse with pneumonia induced by influenza virus. Chin J TCM WM Crit Care 13:198-201

4. Liang YX, Liu XL, Zhang LJ, Wang RF, Hu XH (2018) Experimental study on the effect of the soup of Trollius chinensis from different extraction methods on cell proliferation and antivirus activity in vitro. J Med Res 47:100-105

5. Wang TY, Li DL, Fang MY, Wang QQ, Liu SY, Geng D (2018) Content assay of five components in Jinlianhua decoction by HPLC. Drug Eval Res 41:1053-1056

6. Ge H, Wang YF, Xu J, Gu Q, Liu HB, Xiao PG (2010) Antiinfluenza agents from traditional Chinese medicine. Nat Prod Rep 27:1758-1780

7. Li R, Wei W, Qiao X, Liu J, Liang H, Ye M (2015) Chemical profiling of scutellaria barbata by ultra high performance liquid chromatography coupled with hybrid quadrupole-orbitrap mass spectrometry. J Chin Pharm Sci 24:635-646

8. Yang B, Liu Z, Wang Q, Xia P (2018) Chemical interaction between Lilium Brownii and Rhizoma Anemarrhenae, the herbal constituents of Baihe Zhimu decoction, by liquid chromatography coupled to hybrid triple quadrupole linear ion trap mass spectrometer. Biomed Chromatogr 32:e4118

9. Ma XY, Xie CX, Liu C, Song JY, Yao H, Luo K (2010) Species identification of medicinal pteridophytes by a DNA barcode marker, the chloroplast $p s b \mathrm{~A}-\operatorname{trn} \mathrm{H}$ intergenic region. Biol Pharm Bull 33:1919-1924

10. Wang RF, Yang XW, Ma CM, Liu HY, Shang MY, Cai SQ, Hee J, Zhang QY (2004) Trollioside, a new compound from the flowers of Trollius chinensis. J Asian Nat Prod Res 6:139-144

11. Cai SQ, Wang RF, Yang XW, Shang MY, Ma CM, Shoyama Y (2006) Antiviral flavonoid-type C-glycosides from the flowers of Trollius chinensis. Chem Biodivers 3:343-348

12. Peng YS, Liu LJ, Zhao C, Guo LN, Wang RF (2015) A phenolic acid from the flowers of Trollius chinensis and its anti-inflammatory and antibacterial activities. Chin Arch Tradit Chin Med 33:1349-1351

13. Chinese Pharmacopoeia Commission (1977) Pharmacopoeia of the People's Republic of China, vol I. People's Medical Publishing House, Beijing, pp 359-360
14. Chinese Pharmacopoeia Commission (2015) Pharmacopoeia of the People's Republic of China, vol I. China Medical Science Press, Beijing, pp 21-22 (333, 339, 352-353)

15. Qian Z, Zhou Z, Shi XJ, Han SY, Lv ZW (2014) Advances in studies on the chemical constituents and the extraction and separation of Trollius chinensis Bunge. Chin J Pharm Econ 9:95-98

16. Li X, Pan JX, Chen SG, Xu WC, Jin MR, Ye XQ (2017) Research progress of chemical components and pharmacological action of Pueraria lobata. J Chin Inst Food Sci Technol 17:189-195

17. Yang H, Ma P, Lin MB, Hou Q (2017) Research progress in chemical constituents, anti-inflammatory effect and mechanism of Folium Perillae. Chin J Pharmacol Toxicol 31:279-286

18. Wang XR, An F, Wang SL, An ZX, Wang SH (2017) Orientin attenuates cerebral ischemia/reperfusion injury in rat model through the AQP-4 and TLR4/NF-kappa B/TNF-alpha signaling pathway. J Stroke Cerebrovasc 26:2199-2214

19. Xing ZH, Ma YC, Li XP, Zhang B, Zhang MD (2017) Research progress of puerarin and its derivatives on anti-inflammatory and anti-gout activities. China J Chin Mater Med 42:3703-3708

20. Li DZ, Hu YF, Yang KP (2006) Protective effect of puerarin on endothelial dysfunction of heat shock protein 60 induced specific immunity in apolipoprotein E-null mice. Chin J Integr Trad West Med 26:4-6

21. Wu XA, Qin F, Du MQ (2012) The QSAR study on anti-inflammatory activities of C-glycosyflavones. Lishizhen Med Mater Med Res 23:632-633

22. Jiang KF, Ma XF, Guo S, Zhang T, Zhao G, Wu HC (2018) Antiinflammatory effects of rosmarinic acid in lipopolysaccharideinduced mastitis in mice. Inflammation 41:437-448

23. Zhou D, Li AL, Du GH (2011) Advance in pharmacological research of rosmarinic acid. Chin J New Drugs 20:594-598

24. Choi JH, Chung MJ, Jeong DY, Oh DH (2014) Immunostimulatory activity of isoflavone-glycosides and ethanol extract from a fermented soybean product in human primary immune cells. J Med Food 17:1113-1121

25. Liu Y, Jing YY, Zeng CY, Li CG, Xu LH, Yan L (2018) Scutellarin suppresses NLRP3 inflammasome activation in macrophages and protects mice against bacterial sepsis. Front Pharmacol 8:975

26. Wang S, Wang H, Guo H, Kang L, Gao X, Hu L (2011) Neuroprotection of scutellarin is mediated by inhibition of microglial inflammatory activation. Neuroscience 185:150-160

27. Zhang GH, Wang Q, Chen JJ, Zhang XM, Tam SC, Zheng YT (2005) The anti-HIV-1 effect of scutellarin. Biochem Biophys Res Commun 334:812-816

28. Zhang S, Guo C, Chen Z, Zhang P, Li J, Li Y (2017) Vitexin alleviates ox-LDL-mediated endothelial injury by inducing autophagy via AMPK signaling activation. Mol Immunol 85:214-221

29. Lin MK, Yu YL, Chen KC, Chang WT, Lee MS, Yang MJ (2011) Kaempferol from Semen Cuscutae attenuates the immune function of dendritic cells. Immunobiology 216:1103-1109

30. Onat K, Janine N, Mohamed EMS, Barbara S, Thomas E (2015) Kaempferol is an anti-inflammatory compound with activity towards NF- $\kappa$ B pathway proteins. Anticancer Res 35:2645-2650

31. Jeong HJ, Ryu YB, Park SJ, Kim JH, Kwon HJ, Kim JH (2009) Neuraminidase inhibitory activities of flavonols isolated from Rhodiola rosea roots and their in vitro anti-influenza viral activities. Bioorgan Med Chem 17:6816-6823

32. Wang GF, Shi LP, Ren YD, Liu QF, Liu HF, Zhang RJ (2009) Anti-hepatitis B virus activity of chlorogenic acid, quinic acid and caffeic acid in vivo and in vitro. Antivir Res 83:186-190

33. Yang WS, Jeong D, Yi YS, Park JG, Hyohyun S, Sang HM (2013) IRAK1/4-targeted anti-inflammatory action of caffeic acid. Mediat Inflamm 2013:1-12

34. Qin P, Wei Y, Hou M, Zhao C, Shen Z (2015) A multicenter clinical trial of caffeic acid tablet in treatment of 103 primary immune thrombocytopenia patients. Chin J Hematol 36:103-106 
35. Lee KE, Park JE, Jung E, Ryu J, Kim Y, Youm JK (2016) A study of facial wrinkles improvement effect of veratric acid from cauliflower mushroom through photo-protective mechanisms against UVB irradiation. Arch Dermatol Res 308:183-192

36. Li HX, Zhang Q, Liu YN, Liu P, Wang LY, Li DN (2018) Comparative study on anti-inflammatory activity of luteolin and luteoloside. J Yantai Univ 31:114-120

37. Liu XT, Gu LG, Deng DY, Yu ZN, Wang YQ, Wu J (2016) Effects of baicalin and luteolin-7-O-glucoside on NF- $\mathrm{KB}$ signaling pathway in A549 cells infected with influenza virus H1N1 in vitro. Chin J Tradit Chin Med Pharm 31:1937-1941

38. Wong KH, Razmovski-Naumovskia V, Li KM, Li GQ, Chana K (2015) Comparing morphological, chemical and anti-diabetic characteristics of Puerariae Lobatae Radix and Puerariae Thomsonii Radix. J Ethnopharmacol 164:53-63
39. Tang SH, Chen JX, Wang YP, Wang L, Yang HJ (2012) Research ideas and strategies on the dose-effect relationship of traditional Chinese medicine prescriptions and herbs. J Tradit Chin Med 32:110-113

40. Lv HT, Liu J, Shan H, Fang XL (2011) The optimization of extracting indigo and indirubin from Dyers woad leaves by orthogonal experiment. Food Sci Technol 36:246-250

Publisher's Note Springer Nature remains neutral with regard to jurisdictional claims in published maps and institutional affiliations. 